Wageningen University \& Research

\title{
Water's role in a circular food system
}

Report number: C068/20 / DOI: 10.18174/527866

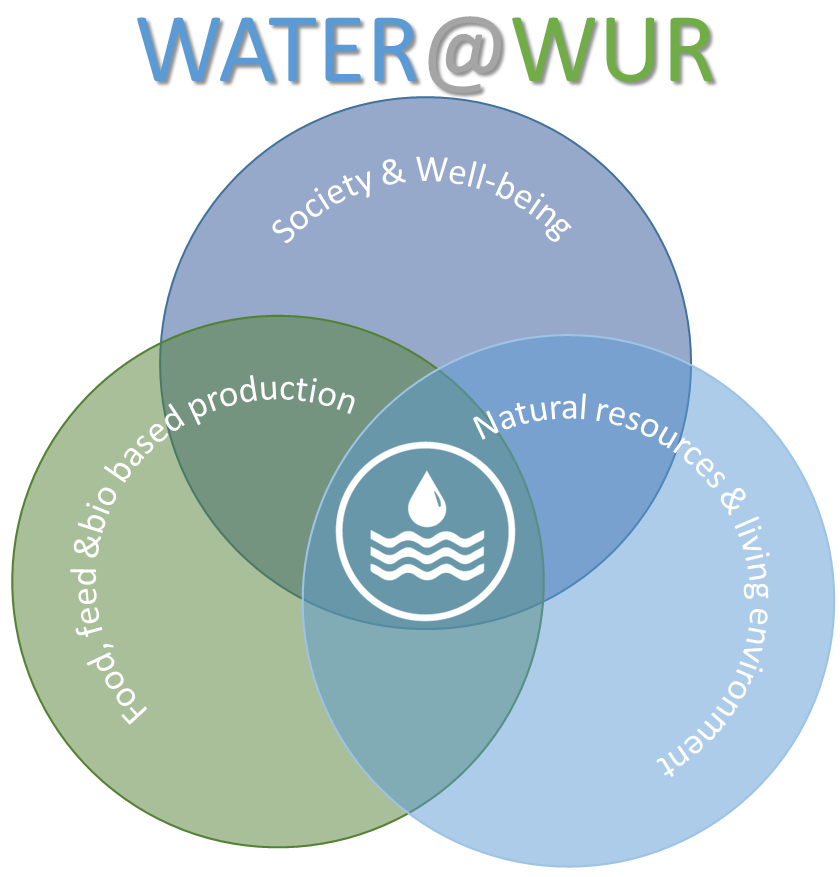




\section{Water's role in a circular food system}

Authors (in alphabetical order):

Adriaan F.G. Antonis ${ }^{1}$, Geert Hoekstra² ${ }^{2}$ Simkje Kruiderink ${ }^{3}$ and Reinier Nauta ${ }^{4}$.

${ }^{1}$ Wageningen Bioveterinary Research, P.O. Box 65, 8200 AB Lelystad, visiting address: Houtribweg 39, 8221 RA Lelystad. Adriaan.antonis@wur.nl

2 Wageningen Economic Research, Prinses Beatrixlaan 582 - 5282595 BM Den Haag. Geert.hoekstra@wur.nl

3 Seconded from Ministry of Agriculture, Nature and Food Quality to Wageningen Marine Research (May 2019-April 2020), Haringkade 1, 1976 CP ljmuiden. s.i.kruiderink@minlnv.nl

${ }^{4}$ Wageningen Marine Research, P.O. Box 77, 4400 AB Yerseke, visiting address: Korringaweg 7, 4401NT Yerseke.

Reinier.nauta@wur.nl

This research project was carried out by Wageningen Marine Research and subsidized by the ministry of Agriculture, Nature and Food Quality for the purposes of Policy Support Research Theme

'Nature inclusive Fisheries' (project no. BO-43.023.02-007-WMR-2). 
Keywords: Circularity, water, food systems

Client: Ministry of Agriculture, Nature and Food Quality

Attn.: S.I. Kruiderink

Bezuidenhoutseweg 73

2594 AC Den Haag

BAS: BO-43-023.02-007

This report can be downloaded for free from https://doi.org/10.1874/527866

Wageningen Marine Research provides no printed copies of reports

Wageningen Marine Research is ISO 9001:2015 certified.

(C) Wageningen Marine Research

Wageningen Marine Research, an institute Wageningen Marine Research accepts no liability for consequential damage, nor within the legal entity Stichting for damage resulting from applications of the results of work or other data Wageningen Research (a foundation under obtained from Wageningen Marine Research. Client indemnifies Wageningen Dutch private law) represented by $\mathrm{Rr}$. Marine Research from claims of third parties in connection with this application. M. S.Th. Scholten, Managing Director All rights reserved. No part of this publication may be reproduced and / or published, photocopied or used in any other way without the written permission

KxK nr. 09098104, of the publisher or author.

WMR BTW nr. NL 8113.83.696.B16.

Code BIC/SWIFT address: RABONL2U

IBAN code: NL 73 RABO 0373599285 


\section{Table of Contents}

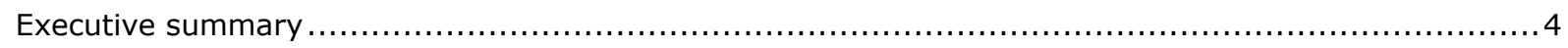

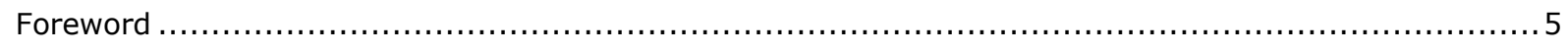

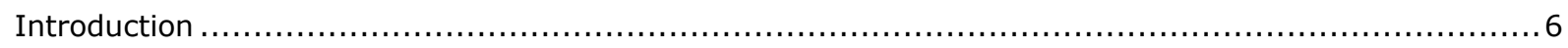

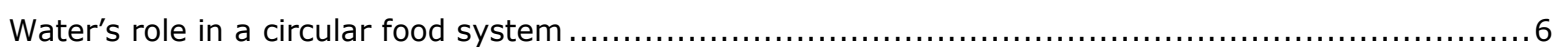

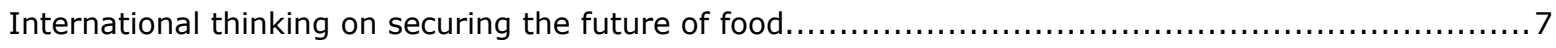

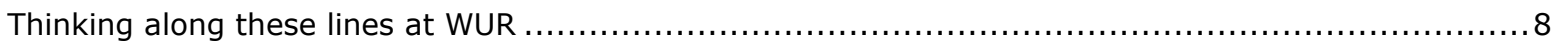

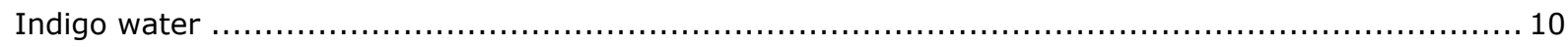

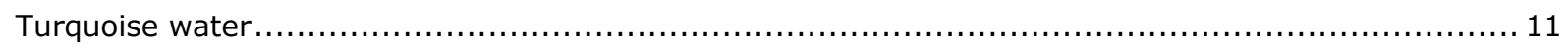

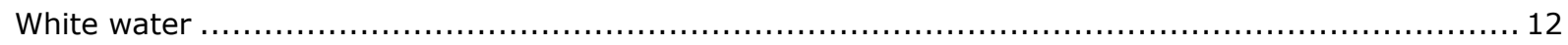

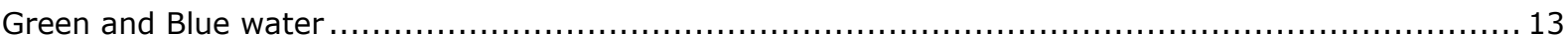

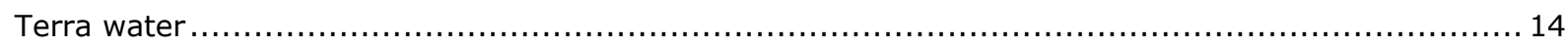

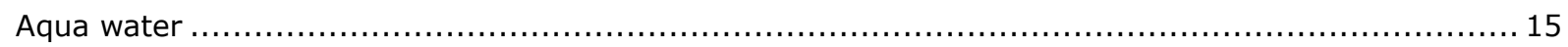

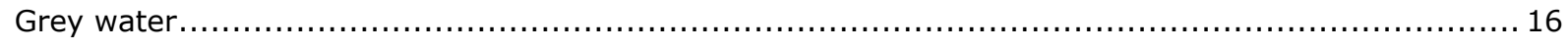

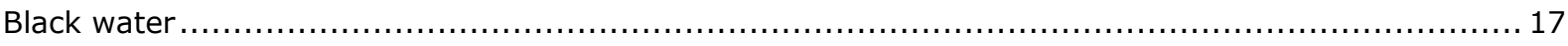

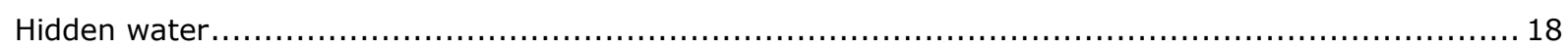

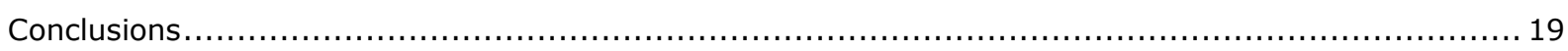

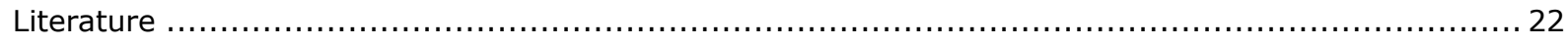

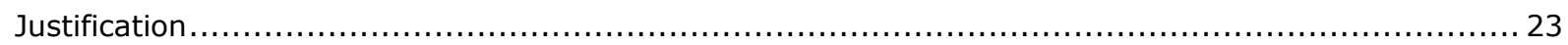

Annex 1 | Benchmark Dutch Ministry of Agriculture, Nature and Food Quality linked to water ............. 24

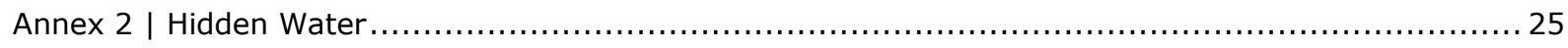

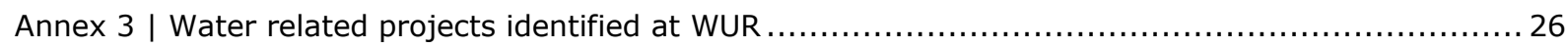




\section{Executive summary}

Water is one of our greatest but finite resources and as such should be treated with special care. The framework for Community action in the field of water policy by the European Commission (Directive 2000/60/EC) states that water should be treated as heritage which needs to be protected. Water can vary in salinity, nutrient levels and levels of contamination (microbiological and/or chemical). For food production as well as for nature conservation, water plays a crucial role. In order to protect our fresh water sources from depletion, we need to reduce, reuse and recycle water in the most efficient way. Safeguard the future of our food supply and to prevent water from running out, the role of water in a circular food system needs to be made transparent. This report is innovative as it aims to open the dialogue about water's role in a circular food system.

Which types of waters could be identified from a circular perspective and to what extend do these interact with each other? The subdivision into green, blue and grey found in literature is enlightening, but falls short of giving a complete circular perspective. These three colours of water often represent a footprint approach related to one product (e.g. to produce one kilogram coffee requires $x$ litres of fresh water). In this report a first exploration towards circular use is made to include nature in the analysis in addition to food production analysis. In order to broaden the dialogue of the representation of the world's potential circular use of water, we have added six colours.

Considering the role and use of water from different angles, will help to:

- Optimize analyses of the food system on how water and how water management contributes to a sustainable food system, as this is currently missing

- Emphasize the urgency to reduce, re-use and recycle water to a larger extend so that there is also water left over for nature.

- Identify knowledge gaps and health risks that will appear when waters are (re)used in a circular way.

- Encourage a required system approach with multidisciplinary expertise as water has a role in highly complex systems that could not be treated by one single stakeholder or one simplistic perspective.

At Wageningen University and Research we will need to stimulate further dialogue, incorporate a system approach (with multidisciplinary expertise) in (combined) research programs and put emphasis on collaboration within our own WUR organisation as well as with others (such as Deltares). A multidisciplinary approach for food production and nature conservation needs to be initiated to ensure that governments can provide direction and facilitate research. In joint responsibility, politics, governments, education, research, but also entrepreneurs and citizens can contribute towards the transition to a sustainable society which prioritizes water's role as a fundamental but also finite resource. 


\section{Foreword}

This report has been written by a multidisciplinary group. Three out of the four authors were part of the agile circularity team at Wageningen University and Research (WUR) which developed new concepts for circular food system thinking. The team spotted a lack of attention and appreciation of the role of water as a finite resource within circular food systems despite the fact that water is indispensable in circular food production. Water determines to a large extent the quality and productivity for food production both on land and at sea. This report should therefore be read as a starting point to open the dialogue about the indispensable role that water plays in the design of food systems within a circular society in which water is also preserved for nature. This is work in progress; this report should not be considered to be covering all aspects nor all research questions. It does however contain the innovation of introducing new colours in order to identify aspects in types of water in addition to the aspects already described in the existing scientific literature of Arjen Hoekstra [1] and Falkenmark et al. [2]. They identified three types of water (green, blue and grey) in order to measure water footprint on a product level. First of all, they refer to green water as rain on land that does not run-off or recharge an aquifer and which is stored in the upper part of the rooted soil or temporarily stays on top of vegetation. Secondly, blue water is described as the consumptive withdrawn from an aquifer, a lake or a river. Often this type of water is used for irrigation (which partially evaporates) for crops or as tap water used as drinking water (also for animals). Thirdly, grey water is referred to as water that is needed to dilute the load of pollutants based on existing water quality standards. Often grey water is potable drinking water that has already been used for laundry, showering, dish washing etc. in households. This report however proposes six additional colours in order to enable finer nuancing when considering the multiple aspects of water in a circular food system. These additional colours are not yet academically assessed or reviewed. We introduce them in this report as a first step in order to illustrate interactions between water colours in the entire water cycle. The intention of these nine colours is to facilitate the identification of opportunities and challenges of circular usages of water at each stage of the cycle. As concepts we found the nine colours to be useful. In reality their boundaries are diffuse and partially overlap each other. 


\section{Introduction}

\section{Water's role in a circular food system}

In her vision 'Agriculture, Nature and Food: valuable and connected'1 Dutch minister Schouten states that "The only way for us to secure the future of our food supplies is to make the transition to circular agriculture. After all, we must prevent soil, water and finite resources from becoming exhausted and the temperature on our planet from rising to unacceptable levels. Circular agriculture provides an inevitable and conclusive solution to these issues." It is her ambition for The Netherlands to become leader in circular agriculture. References are also made concerning resource secure transition thinking for water and fisheries: "Farming, horticulture and fishing are undergoing many changes and aim to meet the demands being made of them by society, nature, the soil, water and the ecosystem. However, at the same time, they are trapped inside the current linear (take-make-discard) production system, which is not future-proof. How can they free themselves? What are the challenges?". The transition towards a circular food system both on land and at sea requires optimizing the lasting use of earth's natural resources. This implies minimizing (reduce) the input of finite resources, encouraging the use of regenerative ones, preventing the leakage of resources and stimulating the reusing and recycling of inevitable resource losses. The objective is to add the highest possible value to the food system with the least possible damage to nature so that future generations, as well as populations elsewhere, can thrive. Food production systems need to be developed in such a way that resources are also shared with "others" over time. It is our understanding that in that context the Dutch Ministry of Agriculture, Nature and Food wishes to know which role water has in such a circular food system. The question of availability of sufficient fresh water to enable food production is not new. However, even in The Netherlands (globally renowned by their state of the art knowledge of water management), addressing the scarcity of fresh water is becoming more urgent after a third year in a row of dry summers. In 2018 there was already a strong increase of fresh water usage by Dutch agricultural companies ${ }^{1}$ (Figure 1). The water cycle (from mountain to sea and back again through rainfall and other precipitation) is in itself circular. Even with this awareness it is remarkable, and concerning, that the current usage of water is frequently linear. In dry seasons Dutch companies and citizens are both draining natural bodies of fresh water as well as depleting the scarce potable tap water ${ }^{2}$. The graph below shows how in 2018, a particularly dry year, the water usage increased dramatically. The trade-offs of this (linear) use, as more dry spells are expected, need to be studied. An exploration of the role of water in a circular food system is therefore a valuable analysis in the overview of the overall sustainable use of water in The Netherlands (and elsewhere).

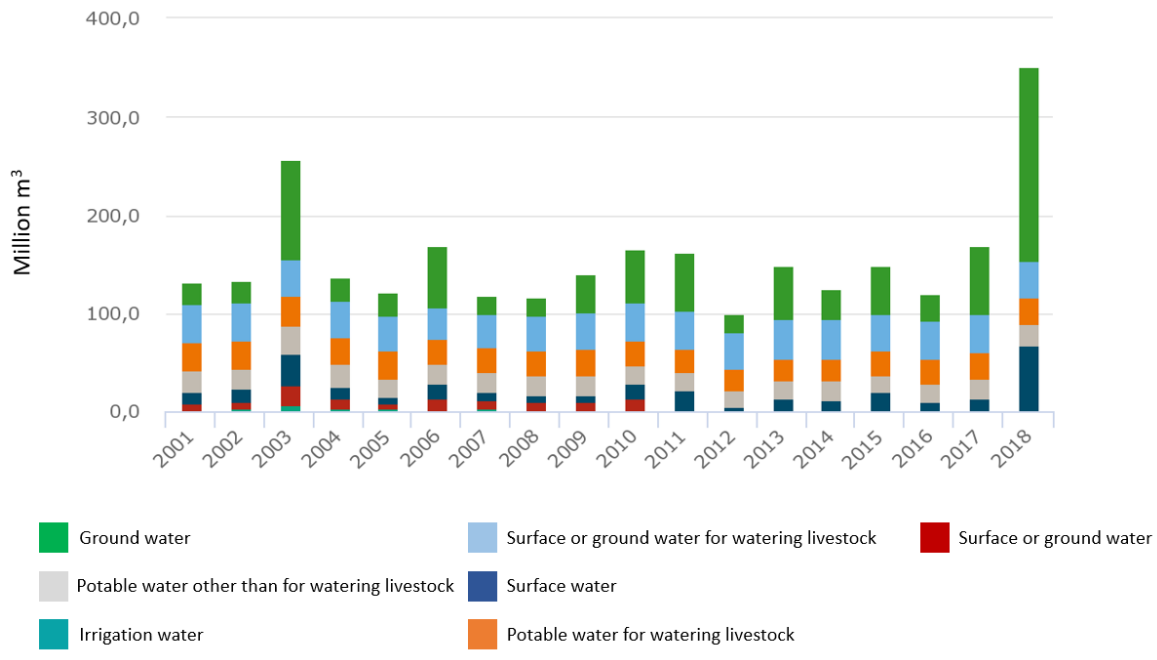

FIGURE 1 FRESH WATER USAGE BY DUTCH AGRICULTURAL COMPANIES (WAGENINGEN ECONOMIC RESEARCH, 2020)

\footnotetext{
${ }^{1}$ Wageningen Economic Research, 2020. https://www.agrimatie.nl/watergebruik land-\& tuinbouw

2 Financieel Dagblad, 2020. https://fd.nl/achtergrond/1345539/droogte-sla-een-eigen-grondwaterbron
} 
Much attention has gone, quite rightly so, since the launch of the minister's vision, to healthy soil, as that is the basis of circular agriculture (“Kringlooplandbouw”). Minister Schouten's ambition however has always been to develop a coherent circular transition both on land and at sea (including rivers and lakes) which is why "water" is mentioned more than a 100 times in her vision, in the realization plan as well as in her benchmark to assess policy (see annex 1). Fresh water, enough of it and of good quality, as well as the nutrients that it carries will be the main focus of this report as both of these aspects are at the forefront of lasting sustainable food production. Less than an estimated $3 \%$ of total water volumes on the planet is fresh and only around $1 \%$ is drinkable. According to outlooks by 2025 , half of the world's population will be living in waterstressed areas (WHO, 2019) ${ }^{3}$. Whether the quality is 'good' depends on the use of the water. For food production on land fresh water is mostly needed. Water however also carries viruses, micro-organisms, spores, toxins, hormones, antimicrobial residues, residues and metabolites of medicinal products and heavy metals which can be a health risk to living organisms. This too will be reviewed as transitioning from linear to circular water use in food production systems brings opportunities but also new challenges.

\section{International thinking on securing the future of food}

Stewardship of the planet is necessary to ensure that we can continue to produce food in the future as well as ensure that biodiversity and nature thrives. Last decades' "people-planet-profit" thinking has evolved into a transition thinking limited by our "one planet" for all branches of the economy in which the biosphere marks the outer boundary. The Sustainable Development Goals (SDG's) were internationally endorsed in 2015 as the agenda for sustainable development to be achieved by 2050. In 2016 the Stockholm Resilience Centre presented a visualization of these SDG's in a "wedding cake" (Figure 2) in order to showcase the cascading of priorities. Instead of "cherry picking" an SDG or a social, economic or nature focus, it was suggested that the economy should serve society so that it evolves and thrives within the safe operating space of the planet. The Farm to Fork Strategy of the European Commission of May 2020[3] is at the heart of the European Green Deal aiming to

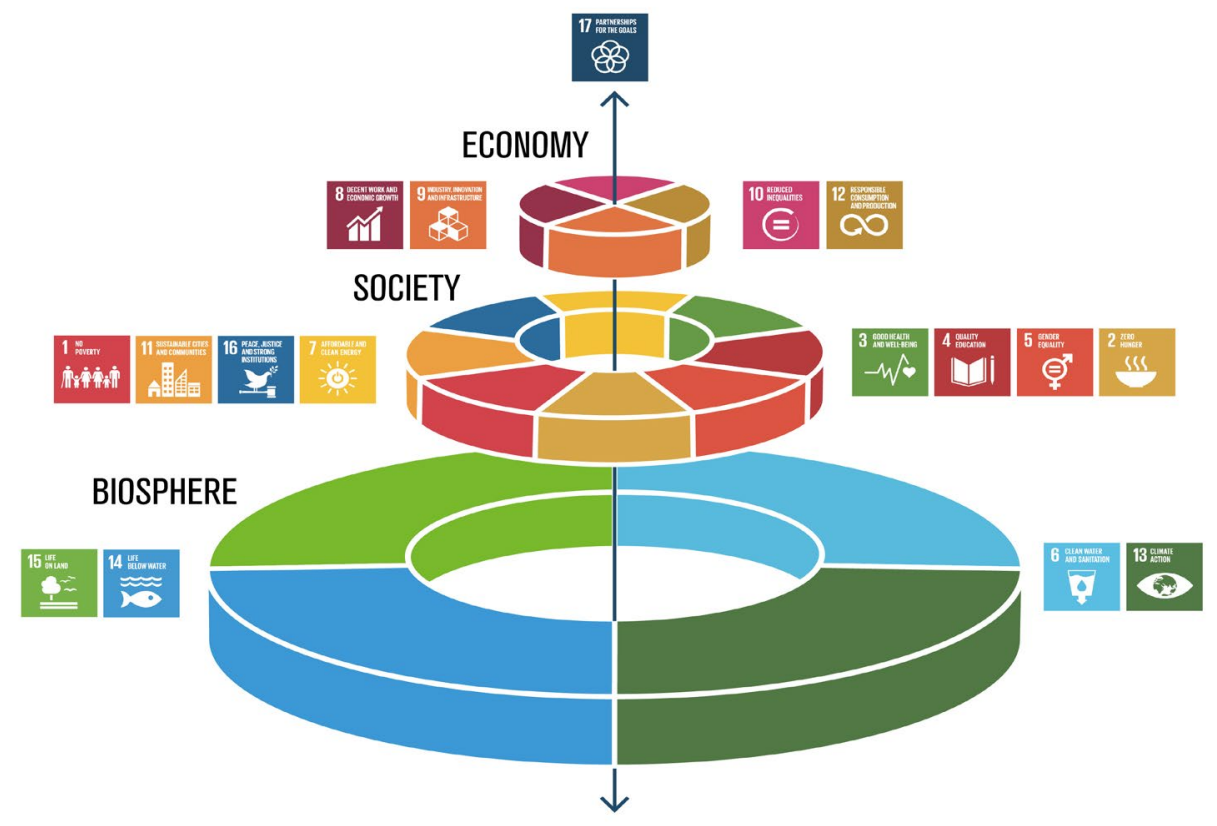

FIGURE 2 A VISUALIZATION OF THESE SDG'S IN A "WEDDING CAKE" SHOWCASING THE CASCADING OF PRIORITIES (STOCKHOLM RESIDENCE CENTER, 2016)

${ }^{3}$ World Health Organization (WHO), 2019. https://www.who.int/en/news-room/fact-sheets/detail/drinking-water Water's role in a circular food system | 7 
develop a "fair, healthy and environmentally-friendly food system". The strategy focuses first on the limitations of our planet and then formulates ambitions to develop legislation that will become the global standard for sustainability.

Those sustainability ambitions therefor clearly start with the biosphere (outer, bottom biggest ring) which is made up of land, climate (air) and two water SDG's. One that aims to ensure availability and sustainable management of water and sanitation for all (SDG-6). And the other that aims to conserve, as well as sustainably use the ocean, the sea as well as the natural bodies of water (SDG-14). Clearly, water can be fresh, salty or brackish as well as natural or "processed". Some water is nutrient rich while some other have been proactively stripped of nutrients. These different water types all have a unique role to play within a circular food system.

\section{Thinking along these lines at WUR}

Wageningen University and Research (WUR) has been developing circular agriculture thinking based on much of the (biosphere) work of Professor Imke de Boer as well as Professor Martin van Ittersum [4]. Professor Jaap van der Meer, within the "Circular team" ${ }^{4 "}$ of WUR, developed an aquatic narrative for circular food production ${ }^{5}$. This analysis brings to the forefront the trade-offs of nutrient use for food production and/or nature conservation. Due to this nutrient based narrative an extra lens was provided to view circular food systems from both land and sea. This concept will be addressed in this report as it helps unifying the assessment factors independent of whether the food production is sea or land based. In this report a conceptual framework (Figure 3) has been developed in which different colours have been assigned to different roles of water with the intention to facilitate circular thinking. Each colour stands for a different characteristic of waterflows that goes beyond fresh, brackish and salty or SDG-6 (clean water) and SDG-14 (life under water). It builds on Hoekstra's work on water footprint in which he defines green, blue and grey water[1]. In order to broaden the water discussion, from linear to circular, we have introduced additional colours to these three renowned in scientific literature. These colours are not yet academically assessed. Our intention is however that they help to start the debate about the role of water for sustainable food production as well as help eliminate blind spots and aid the "discovery" of resources within each water colour that might now, in a linear system, be seen as "waste". This colour scale will help in the providing of an overview of current knowledge, as well as identifying blind spots with the objective of sharing knowledge as well as suggesting where further research might be needed.

\footnotetext{
${ }^{4}$ A temporary think tank at WUR an circular food systems including the sea

${ }^{5}$ Van der Meer, in prep 2020: "Limits to marine food production"
} 


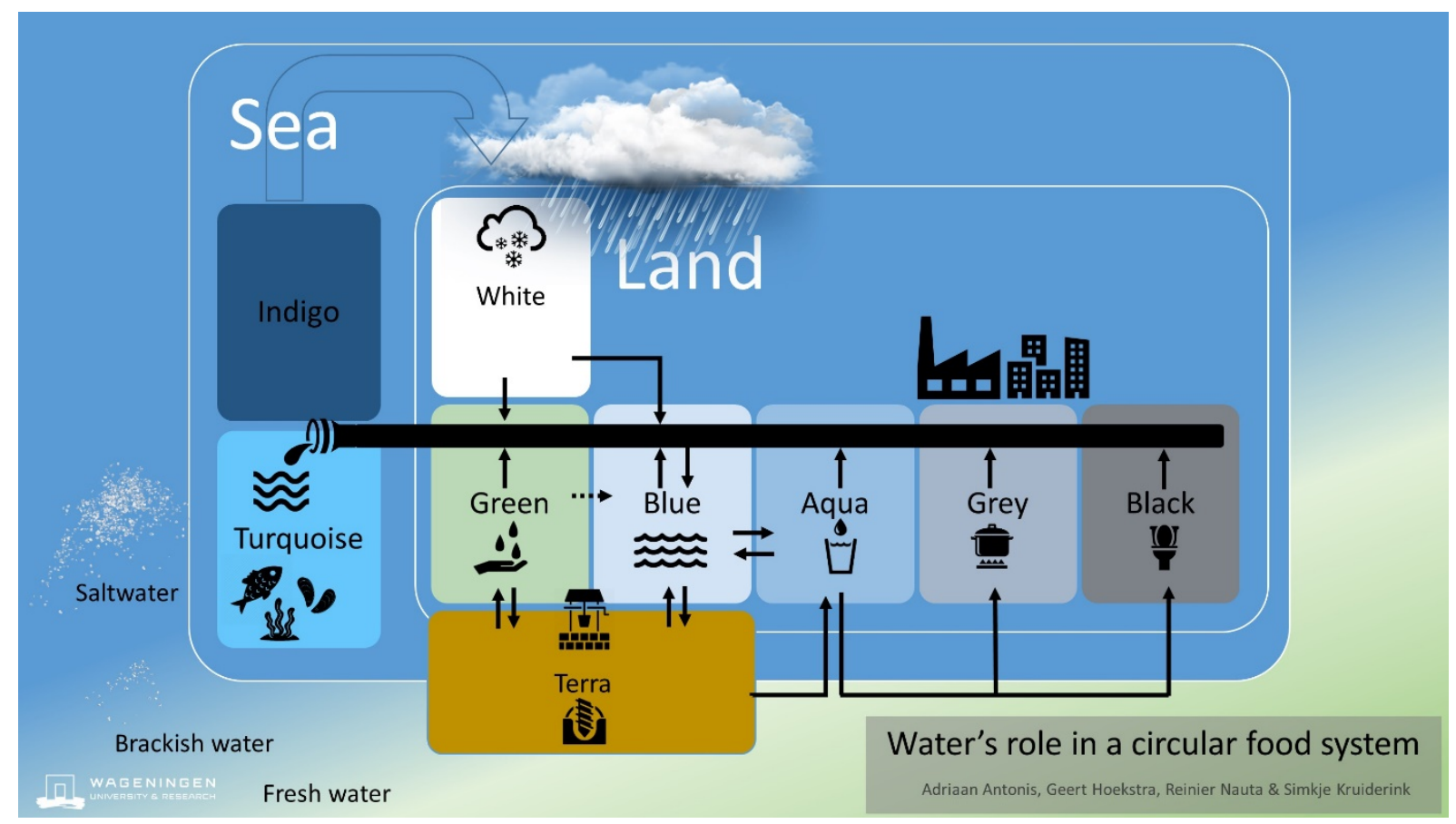

FIGURE 3 INFOGRAPHIC ON THE ROLE OF WATER IN A CIRCULAR FOOD SYSTEM

In aquatic research a clear distinction is made between fresh water and marine systems. This distinction is made in order to facilitate the answering of scientific questions. Water is by its very nature circular as evaporation from the sea feeds, via precipitation (white), the soil (green) as well as replenishing rivers and lakes (often defined as blue) and underground reservoirs (terra) to be used as drinking water (aqua) or in industrial processes (grey) as well as sanitation (black) after which it returns (filtered) back to the sea (brackish: turquoise) and ocean (indigo). The "source to sea" 6 concept, which links fresh water (blue and green), as a carrier of human produced "waste" (grey and black), to the sea (turquoise and indigo), focuses on the circular economy as a solution to produce less waste, not more food. The "source to sea" concept focuses on the big water circle. Agriculture often focusses on - linear - rain water (white), irrigation (green and blue) as well as ground water (terra). Neither focus much on the smaller water (and nutrient) cycles. This paper aims to join up both worlds (natural and industrial) as well as small and large water cycles, in order to produce food with less waste as well as sharing with nature. Lastly we will also focus on "hidden" water (invisible). That is water which the National Geographic i highlighted as water being an element in or imported (or exported) food.

WUR's focus is to research both healthy food as well as a health living environment. Not wasting water, as well as the nutrients that it carries, is being researched throughout WUR, be it for food, feed or bio based production, natural resources and living environment or society and wellbeing. In this report we will limit ourselves largely to showcasing the role of water from the technical biosphere perspective as part of the circular society discussion. Equity, dealt with in the sphere of what kind of a society we wish to transition to, we will not address in this report as it is worthy of a dedicated review concerning the transition to a circular society which is a much more profound transition than a transition to a circular economy. Issues such as whether it is equitable that The Netherlands import "hidden" water from regions of the world where water is even more scarce than in The Netherlands will not be addressed. This paper will include a description of each colour of water, the linear use as well as what the opportunities (and potential risk's) are of its use within circular food system. It will also showcase projects and provide an overview (annex 3 ) of all the water related projects that we encountered when searching for circular examples. This report is an exploration of water's role in a circular food system. The aim is to open a dialogue about the indispensable role of water for circular food production and life on earth. As well as how to safeguard the scarce fresh water with a lasting use.

\footnotetext{
${ }^{6}$ https://www.siwi.org/publications/implementing-the-source-to-sea-approach-a-guide-for-practitioners/ Water's role in a circular food system | 9
} 


\section{Indigo water}

The largest reservoir of water on this globe are the world's oceans and the seas combined. This basin alone covers over $70 \%$ of the earth's surface and contains $98 \%$ of all the water present on the globe. Marine water furthest away from land and of over $>200 \mathrm{~m}$ of depth we assigned the colour 'Indigo'. Due to the low nutrient levels, far from the shore and on the surface only limited quantities of life can be sustained. These areas can technically be seen as "deserts", mainly housing migratory animals passing by in these parts of the ocean[5]. Salt water, combined with the lack of nutrients, limits the suitability for food production. Globally this large body of water does however play an important transportation role acting as a 'road' for both goods in ships as well as for pollutants in the water itself (oil, chemicals, plastics, nuclear). Both threatening the marine life passing through as well as interfering with migratory routes of sea life put pressure on the world's oceans and seas ecosystems.

In contrast to the surface waters, deep water of the world's ocean far from land do contain larger amounts of nutrients [6]. These nutrients are transported by the global ocean "conveyor belt". This 'belt' is a continuous system in which a constant moving current connects water in the ocean. In this way nutrients, but also contaminants, are transported around the globe [7]. Yet, due to the ocean's overall depth, the large timespan it takes for nutrients to resurface and the deposition on the seafloor, this part of the system is seen as a major sinks for nutrients. Only at a few locations in the world this nutrient rich water comes to the surface (upwellings) forming vibrant spots in which life thrives abundantly [5]. Utilizing these deep sea nutrients in natural upwelling areas as well as creating artificial upwelling area by pumping up deep water, nutrients can be redirected towards the circular system via food, derived from harvesting natural sources or cultivated on these nutrient fluxes [8]. Actively pumping nutrient rich water from the ocean deep for food production however has not yet been proven to be economically viable.

Besides economic considerations extracting deep sea nutrients also has much broader considerations due to its potential effect on the other side of the world due to the interlinkage of the ocean's water systems. The ethical question of who 'owns' the nutrients and has the right to utilize them surfaces. Similarly the same question can be raised concerning who owns the pollutants and should be tasked with the clean-up of them. 


\section{Turquoise water}

In aquatic research a clear distinction is made between fresh water systems and marine. This distinction underlines the largely linear approach of answering scientific questions. The area where these two systems meet, is the area in which water becomes increasingly saline (brackish) as it moves towards the sea and the ocean. This transition area, embodied by delta's, estuaries and coastal zones (the part of the sea that is under influence of terrestrial processes), are characterized by these saline conditions and the affiliated fertile soils. It is this type of water, brackish to saline and an effluent of natural basins, that we assign the colour 'Turquoise'.

Food production in saline/brackish water depends strongly on the level of salinity and nutrient availability both on land and at sea. These factors determine what can be cultivated and/or harvested and how much. Work done by prof. dr. J. van der Meer, senior researcher at Wageningen Marine Research has shown that the marine system has a much higher efficiency in taking up the nutrients than terrestrial systems do [9]. This results in an increased flux from primary producers (e.g. algae and seaweed) to higher trophic levels (carnivores) than is the case on land where much of the nutrients end up in the detritus (non-food) system. The implication of this reversed biomass pyramid is that if production of lower trophic biomass in marine systems is significantly increased (e.g. seaweed cultivation), the balance of the natural system could be altered severely causing a possible major ecological impact as nutrients are diverted from the natural system to for example seaweed production (for human use). Minister Schouten, in her vision, focuses largely on fisheries concerning food production from aquatic sources. This 'extraction focus' (such as quota for fisheries) can be shifted towards a policy based on nutrient availability. Thereby transitioning from a linear (sectorial) approach to more circular (system) thinking. Such a transition in thinking would lead to policy focusing on trade-offs of nutrient availability evaluating whether to harvest food (seaweed, shellfish, fish) or reserve nutrients for nature conservation (or the blue bio-economy). Additionally policy could also be developed in coastal waters on whether nutrients should be retained (in order to bring it back - circularity) on land or be allowed to flow out to the highly productive sea instead.

For the terrestrial food production in these area's salinity is a major factor determining food production. Due to climate change the areas in which saline water is present, is increasing. Saline water intrudes more and more inland causing multiple major challenges. With increasing salinity, freshwater reservoirs become less suitable for drinking water ('Blue') but also threatens 'Green' water as organisms (e.g. agricultural crops) are largely not adapted to dealing with this increase of salinity [10]. Productivity loss for farmers as well as and biodiversity loss on land in nature in these areas calls for adaptation and mitigation research as well as long term adaptation planning/policy.

The Netherlands, being one of the most pronounced delta areas of Europe, has to cope with this change on a major scale. With increasing salinity, drought periods and reduction of available fresh water, WUR is investigating saline agriculture, as well as alternatives for agriculture such as hydroponics and aquaculture. This is largely done from a terrestrial point of view, of which a significant amount of work on this topic is executed by the Environmental Sciences Group and Wageningen Plant Research. Research is executed with the program 'Duurzaam waterbeheer' as well as the KB-program Food security and valuing water. Opportunities of usage of brackish systems by combining land and sea utilization in coastal areas are being investigated in order to broaden production capacity as well as regaining nutrients (as phosphorus, nitrogen and carbon) which otherwise would largely have been lost to the deep of the ocean.

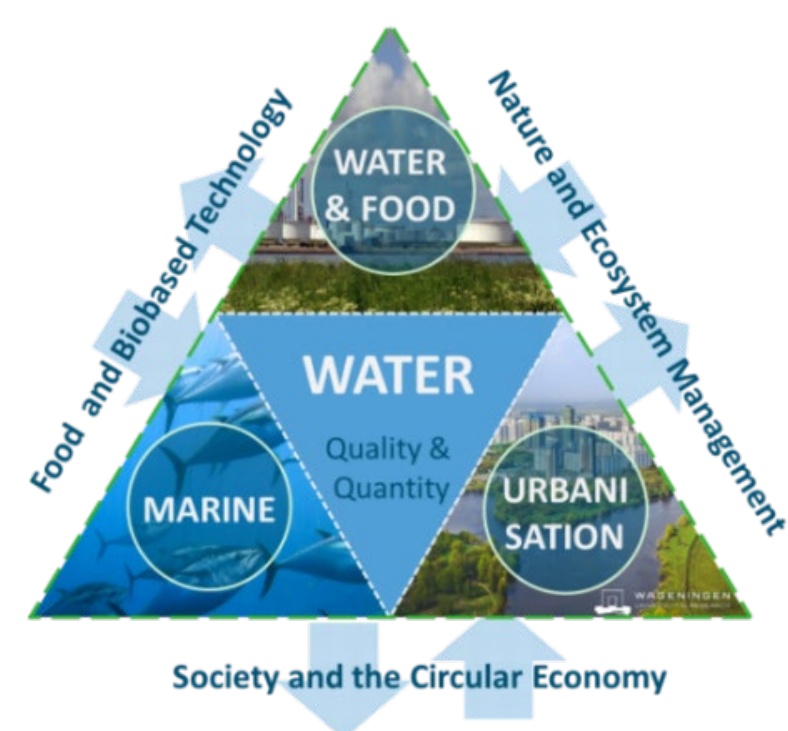

Water's role in a circular food system | 11 


\section{White water}

We assigned the colour white to water in a solid, liquid or gas substance as atmospheric water (in the sky) that has not (yet) hit the surface of the earth (land or sea) after which it becomes (at sea) indigo and turquoise again or (on land) green and/or blue. This colour underlines that the natural water cycle is circular in itself. White water refers to rain (in any form) and therefore also clouds and ice or snow as well as that water released by the melting of ice or snow ${ }^{7}$.

In a linear system with a growing world population, white water is often underutilized while scarce fresh drinkable (aqua) water is scarce. For instance, melting water from mountains is intensively used by cities and communities as drinking water, for food production (irrigation) and hydroelectric plants while rain water is often ineffectively used. Indirectly rain is used by rainfed crops as it is absorbed by land, lakes and rivers. In The Netherlands however much of the rain that falls on pavements or on buildings is wasted. In a circular system (white) rain water would be captured instead of ending up in sewers and drained out to sea. This rain water stream could be used by households, for flushing toilets and washing clothes thereby reducing the pressure on scarce fresh (aqua) drinking water. Ideally a percentage of the captured rain water would be filtered and purified in order to become usable for even more purposes by human beings. Water Smart Cities [11] is an example of project discussing the usage of "white water" in cities. As the world urbanizes climate change will have a larger impact on cities - In 2050 worldwide over 6 billion people will live in cities. Europe is one of the most urbanized continents in the world. Most cities are designed to drain rainwater and waste water outside the city limits, and to import water from rivers and well-fields far outside the city. Several recommendations are provided within the report of Water Smart Cities about how to reuse rain water and reduce the wastage of it. For instance, retention of rainwater where it falls to reduce surface run off on e.g. green roofs, (communal) rain gardens, curb extensions. Furthermore, water storage: Rainwater harvesting systems collect rainwater from roofs and other paved surfaces for on-site use (for example rainwater tanks, water squares). Storages or detention basins can temporarily hold back water and thus prevent floods. High Noon ${ }^{8}$ is a project with adaptive strategies in the Himalaya mountains of North India to extensively use white water by reusing and recycling other sources of water (grey, black and green) for irrigations and the food production, preferably no white water and less blue water (from rivers and the lake) were needed. The meltwater and scarce summer monsoon rains are the main sources for water in these areas. Another example of the reuse rainwater is the "more per drop"[12] concept of horticulture in Dutch greenhouses. Also in The Netherlands there is growing need to capture rain water to irrigate crops and as drinking water for cattle in the drier summer periods [13]. Efficient water use and reuse of waste or saline water sources will lower the water footprint and provide growers with a license to produce. A Dutch company Aqua Terra Nova has designed a water management concept for 190 ha of greenhouses in the Westland area, responding to problems such as a lack of surface water, regular flooding, high waste discharges and high water demands. The concept is based on a centralised drainage system, combined storage, buffering, treatment and irrigation. The benefits of the system are: a $50 \%$ land use reduction resulting from water storage underneath the greenhouse, the reuse of waste water and zero emission of nutrients and chemicals.

\footnotetext{
${ }^{7}$ It is debatable whether melting water has to be defined as white water, as it is often contaminated with the soil (green) or rivers and lakes (blue). This requires further research (e.g. literature review) to justify either one of both possible definitions.

8 Biemans \& Terwisscha van Scheltinga (2012). HighNoon: adaptation to changing water resources availability in northern India.

https://www.wur.nl/en/project/HighNoon-adaptation-to-changing-water-resources-availability-in-northern-India-.htm
} 


\section{Green and Blue water}

We define green and blue water as white water that enters natural water bodies on land or soil itself. This can be rivers, lakes (blue) or moisture (often via rain) at the soil (green). It refers to the precipitation of water on land that does not run off or recharge groundwater. It is also stored in the upper levels of soil or temporarily remains on top of the soil or vegetation. Moreover, a part of the green and blue water can evaporates or transpire via plants (and so turn into white water again). There is also melting water that comes from ice shelves but this water ends up in the oceans (indigo), coastal waters (turquoise) or rivers (green). Meltwater provides drinking (aqua) water (sometimes after filtering and purification) for a large proportion of the world's population, as well as providing water for irrigation and hydroelectric plants in a linear system. Often fresh water scarcity is associated with drinkable (aqua) water. However, green and blue water is getting more and more scarce as well. Green and blue water is (even) in The Netherlands and European agriculture required more and more for irrigation. In particular in seasons of drought when hardly any rain (white water) is a main source to replenish green and blue waters systems. Moreover, there are many places in the world where intensive rain showers causing floods (and run off of nutrients). Climate change could increase these extremes of green water shortages or surpluses [14].

In our current linear food system frequently ground water (terra, see this 'terra water' chapter), water from rivers or lakes (blue) or drinking water (see 'aqua water' paragraph) is used to irrigate the crops and vegetables on land. Though by far most crops worldwide are still exclusively rain (white) fed. These last summers the finiteness of blue and green water became clear in The Netherlands due to droughts. In 2018 the Dutch agriculture used 302 million cubic meters of fresh water. This was 150\% more than in 2017 and 50\% more compared to the another dry year of 2003[15]. In 2018 Dutch agriculture used almost four times more surface and ground water than in the previous year. Many ditches were and are (in 2020 the same or even worse is expected) at a lower level compared to these blue water levels of the last decennia due to the tapping up of blue water, from ditches, for watering of cattle and the irrigation of crops. Several reports estimate that $70-80 \%$ of our collective fresh water is used for irrigation worldwide, of which the majority of it is green, blue and aqua water.

In a circular system, blue and green water is used sparingly (drip irrigation) or repeatedly (cleaning/processing and then irrigation) as well as stored (rainfall) to be reused afterwards. Examples are basins near agriculture lands, greenhouses and on top of buildings rainwater storage to reuse (later on) for irrigation, flushing toilets, gardening etc. By making more use of vegetation in cities instead of only stones and concrete in the nearby future, rain could be better collected, stored and reused (Wageningen Plant Research, 2019)[16]. By this reuse, of scarce green water not only is utilization optimized from a resource scarcity perspective but it also avoids unnecessary use of green, blue and terra waters.

Next to the quantity of green and blue water, there is a need for high quality of it. In the Netherlands WUR frequently monitors the chemical and microbial quality of blue and green waters. According to WUR studies (Wetland Restoration Ecology) the quality of ditches and ponds in the Netherlands are especially concerning by their low quality. Often there is solely attention for the quality of lakes, channels and rivers but less for the ditches and ponds in the Netherlands ${ }^{9}$.

With expected more hot summers in the Netherlands more attention is needed for the quality and supply of green and blue waters. An example of a project that utilizes blue water in a circular perspective is "feeding the pond (instead of the fish)"[17]. Here the health of the blue water is the priority in food production. In this eco-friendly aquaculture system bacteria and microbial community flocks are directed to be feed for fish and shrimps in the pond (WUR Aquaculture \& fisheries, 2019) ${ }^{10}$ [18].

\footnotetext{
${ }^{9}$ https://resource.wur.nl/nl/wetenschap/show/Kwaliteit-van-slootwater-is-slecht.htm

${ }^{10}$ WUR aquaculture \& fisheries, 2019. NUTRITIOUS PONDS. https://www.wur.nl/en/project/NUTRITIOUS-PONDS-.htm
}

Water's role in a circular food system | 13 


\section{Terra water}

Groundwater stored in aquifers we assign the colour terra as we feel it required specific attention ${ }^{11}$. An aquifer is an underground layer of water-bearing rock, rock fractures or unconsolidated materials (gravel, sand or silt). Aquifers occur from near surface to deeper than 10,000 metres. Those closer to the surface are used for water supply and irrigation. These water sources can be (but are not always) naturally replenished by surface (green) water and act as a natural storage that can buffer against shortages of surface water. Some terra water is finite. Once pumped up it will not be replenished for hundreds of years. This finiteness is the reason we feel it's important to single it out. Terra water makes up about thirty percent of the world's fresh water supply and is roughly equal to the total amount of freshwater stored in the snow and icepack, including the north and south poles. Due to an increasing claim to terra resources, the finiteness of this source is increasingly visible.

In many areas, climate change is likely to increase water demand. Depletion of terra resources, due to groundwater pumping, has been identified in numerous global aquifers, suggesting that extractions have exceeded natural recharge rates in critically important global freshwater supplies. This problem is exacerbated by rising sea-levels, that increases seawater intrusion. Seawater penetrates the aquifers diffusing in from the sea and the ocean. Under the influence of continuous evaporation, the salt concentration of the aquifer water may increase continually and eventually cause an environmental problem.

Terra resource are less susceptible to microbiological pollution than surface water, because the soil and rocks through which ground water flows screen out most of the micro-organisms. However, occasionally they do find their way into our freshwater supply. The more superficial water is abstracted from the terra resources, the greater the risk that this water is microbiological contaminated. Diagnostics focuses on the detection of Escherichia (E.) coli as indicator for the degree of faecal contamination.

${ }^{11}$ In Hoekstra's analysis "terra water" is a part of green water (not given a separate colour) 


\section{Aqua water}

Aqua is the colour of water we assign to water that is safe to drink (drinking or potable water) or to use for food preparation. Access to safe drinking water is essential to health, a basic human right and a component of effective policy for health protection. The definition of safe drinking water is that it does not represent any significant risk to health over a lifetime of consumption, including different sensitivities that may occur between life stages. Those at greatest risk of waterborne disease are infants and young children, people who are debilitated or living under unsanitary conditions and the elderly. Many developed countries specify standards to be applied in their own country. In Europe, this includes the European Drinking Water Directive ${ }^{12}$, whereas others have their own standards. For countries without a legislative or administrative framework for such standards, the World Health Organization (WHO) publishes guidelines on the standards that should be achieved ${ }^{13}$. The WHO categorizes potable water contamination as organic, inorganic, radiological and microbiological, and includes measures of acceptability of taste, smell and appearance.

In most developed countries, tap water meets the drinking quality standards, even though only a small proportion is actually drunk or consumed in food preparation. Most of this valuable water is used for washing, cooking, irrigation and the flushing of toilets. The noble aim, for example, of providing all of humanity with flushing toilets could lead to a very significant use of aqua water. Making potable water even more scarce.

A circular food system aims to minimize the use of resource inputs and the creation of waste. In practice this could imply that tap water only be used for drinking purposes or food preparation and not for washing, irrigation or the flushing of toilets. Other water or -waste sources (green, grey or black) should be used for watering animals, washing, flushing the toilets and irrigation. Spilled tap water spill should be reused, instead of draining it through the sewer.

\footnotetext{
${ }^{12}$ European Drinking Water Directive: https://ec.europa.eu/environment/water/water-drink/index en.html

${ }^{13}$ Guidelines for Drinking-water Quality, Fourth Edition; World Health Organization; 2011

https://www.who.int/water_sanitation_health/dwq/fulltext.pdf

Water's role in a circular food system | 15
} 


\section{Grey water}

Grey is the colour we assign to water that results after aqua water is contaminated by households (e.g. by using it for laundry, dishes and bathing) or after being used in food processing or by animals (e.g. fruit and vegetable processing, milk rinsing, aquaculture fish basins wastewater, fish processing etc.). The main challenge of recycling or reusing grey water streams is the risk of contamination of the water and associated health risks for humans and animals. Contaminants to be filtered out of the water can be (an)organic or (artificial) chemical substances or non-biodegradable soaps, other personal care products, human waste (other than excreta in 'black water'), applying medicines, metal, detergents, (micro) plastics etc.

In production companies, grey or process water, in this context is a common name for water which cannot be classified as drinking water and which is used in connection with e.g. technical plants, processes in production companies, heat and power plants and institutions. The water is mostly fresh, but in some cases can be saline or brackish. These waters can contain viable volumes of nutrients like phosphorus, protein and omega-3 fatty acids (e.g. fish and vegetables processing water), antioxidants, minerals and lipids. Nutrient flows in the Dutch Delta of Zeeland link food production on land (e.g. potatoes) to that near the shore shellfish (e.g. mussels and oysters). Here the eutrophication via rivers of phosphorus and nitrate from fertilizer used at land by farmers, could provide extra nutrients to algae's and shellfish in the deltas. These extra nutrients could also create potentially healthy risks if shellfish filtering the runoff water capture (toxic) nutrients. Furthermore, as eutrophication limits the oxygen in water it could also harm the biodiversity of other marine species and organisms. Nutrients frequently end up in the grey water of households or food production companies. Subsequently, these viable substances are often filtered out (at a cost) and afterwards wasted by water treatment companies. Current policy determines that the amount of taxes to be paid depends on the amount of substances (pollutants) found in the water. This does little to incentivise the development of a more circular system in which "waste" is "mined" out as a resource.

In a circular system grey water could be reused after or even without recycling and filtering. For households and companies the reuse of grey water for toilet flushing, washing machines, gardens, cleaning or business processes is already a (prototype) option (used in many green/natural buildings). Especially in building with many users (e.g. apartments, hotels, schools, sport centres, large companies etc.) there is a high amount of grey water available. When grey water is reused instead of blue (drinking) water, it saves potentially millions of scarce drinkable water and electricity otherwise used for recycling contaminated water into blue water. From a bio based or circular economy perspective it is also promising to reuse grey water. Grey water ends up in public sewage systems after which costly treatment plants filter out, and discard, valuable nutrients. Circular thinking is already being applied in some sewage systems in which rain water is being separately collected from grey water for land irrigation (if the quality is sufficient) but also for new circular food and feed applications. In food production blue water is used to clean and process food. As a result many valuable ingredients end up in grey 'waste' water These ingredients like proteins, phosphorus, acids, minerals etc. could be extracted and reused for other food applications. Water treatment companies could filter some of nutrients from the sewage system. Often this phosphorus, ammonia and (partly added) magnesium form 'struvite' which is used as input for phosphor gaining as well as for fertilizers.

An example of a grey water project is the reuse of milking rinsing water to quench the thirst of dairy cows ${ }^{14}$. Another, project is the water used to clean and process sugar beets. Originally, the industry had to pay high taxes to water treatment companies due to the high levels of pollutants in the processing water of sugar beets ${ }^{15}$. Nowadays sugar beets companies have generated a business model in which protein is extracted from the grey water leading not only to a lowering of the water treatment costs, but also extra obtained benefits from the extracted proteins. The same applies to the potato processing industry.

\footnotetext{
${ }^{14}$ Winst uit water - Melkveehouderij. Waterwijzer 2006 https://edepot.wur.nl/58537

${ }^{15}$ https://www.wur.nl/nl/activiteit/Sugar-beet-leaves-for-functional-ingredients.htm
} 


\section{Black water}

Black is the colour assigned to toilet water which includes waste, which contains faeces, urine and toilet paper from (flush) toilets.

- $\quad$ Faeces are defined as solid or semisolid remains (waste) that could not be digested in human's (or animal's) small intestines and are excreted from the body through the bowels. Faeces contain high amounts of organic waste products, a relatively small amount of metabolic waste products and viruses and micro-organisms.

- $\quad$ Urine consists for $91-96 \%$ of water, but also contains inorganic and organic salts, including proteins, hormones, and a wide range of metabolites, varying by what is introduced into the body and depending on diet and health status. Urine is not sterile and does contain a relatively small amounts of bacteria.

Small volumes [19] of faeces (100-200 g/capita/day) and urine (1200 ml/capita/day) are mixed with large volumes of water, in most cases tap (aqua) water. In the most common sanitation concept that black water is transported to a centralized treatment site via a costly and complicated sewer network. Disadvantage associated with this process are loss of valuable resources in terms of plant nutrition, energy and water.

A circular food system aims to minimise the use of resource inputs and the creation of waste. All "waste" should become input for another process; either a by-product or recovered resource for another industrial process or as regenerative resource for nature (e.g. compost). In practice this could mean that we stop using potable (aqua) water to flush human excreta (faeces + urine). That we reduce the amounts of used water in our sewer network and that we extract as many nutrients as possible from sewage enabling a more sustainable food production in the future.

Although black water should be considered as the hidden black gold in a circular food system, there are a few potentially nasty snags. Wageningen Bioveterinary Research, for example, has thought about the potential risks of introducing antitumor viruses (as a novel antitumor-therapy in humans) to farm animals. In our current (linear) system, where human excreta are just drained and burned, this is considered not to be a risk. If this 'black gold' were to be used on our arable land, this could become a serious risk. Other potential, microbial risks that have not been sufficiently identified need to be assessed. 


\section{Hidden water}

Where the majority of the water can be assigned to a colour, there is also a part of the water that cannot be seen. It is therefore that we have not assigned it a specific colour. This type of water, sometimes also referred to as 'virtual water' or 'invisible water', the national Geographic ${ }^{16}$ refers to as 'Hidden water'. This is water which is needed in order to produce food (or feed and other products) which is later imported and exported and thus transferred (hidden) over the global through trade. Largely this covers agricultural products, but also fabrics (cotton, silk and hemp), fish products and other (half) fabricates originating form nature or cultivation.

One of the most profound examples is the production of meat, and especially beef. Cattle not only drink water, but also its feed needed water to grow and stables need to be cleaned. Adding in also the water needed for processing, over 15,000 litres of water is needed to produce one kilogram of beef[20]. If such a product is produced in areas where water is increasingly becoming scares, production or the facilitation of the production, should be re-evaluated. Europe is the largest importer of hidden water worldwide not only in food, but also for feed. This is especially concerning if the imports originate from regions that are depleting their aquifers (thus impacting future generations) or struggle to provide their inhabitants of basic drinking supplies.

Production of goods compete for the availability of fresh water and the application for other purposes such as drinking water or nature conservation. New ways of thinking around the concept of the value of water is needed. Water in The Netherlands is often seen as 'free' making it possible for companies to claim water and utilize it abundantly while also holding the governments accountable for water shortages in times where no rain is falling. In this way the concept of "privatizing profit and socializing the problem" is enforced with the potential of disbalancing the entire system. In the chapter on white water an example of such destabilization is given; the Dutch horticultures and green house cultivation. These companies collect rainwater which is used in the production of the crops. As a result precipitation no longer ends up in natural reservoirs such as surface and ground water systems. Crops sold (exported) have within them water hidden that could not be used by others or elsewhere. Hidden water transported over the globe is, if not returned, in its very nature linear. From a circular perspective the triple-R (Reuse, Reduce \& Recycle) needs to be applied. Choosing more suitable cultivars should be a start to reduce water use in export products if water is scarce (and free). Transporting less water could result in more cost-effective transport and the reuse of the extracted water. By doing so, confiscation of water by the producers is lowered and more water is available for the local needs and the economy. But also weighing in the export value of a crop and/or product against its impact on the local water supply system and charging more in order to reflect the water's value, could form a step towards a more sustainable and circular system. By expressing water in commodities, as has been done by Hoekstra and his colleges at UNESCO and the University of Twente, and by further developing the tool 'Water footprint' for water management, countries, companies and individuals will get a clearer insight into their water needs and usage.

The concept of hidden water shows how large the role of water is in our present economic system, but also how linear its application is. The water needed to produce the products investigated by Hoekstra and his colleagues is described as the water footprint of the products. It is upon this legacy that researchers of WUR are further developing the mapping these water movements, as well as investigating the economic and social effects of the imbalance that hidden water creates within society as well as between nations. This work is done within the group of prof.dr.ir. Petra Hellegers, at the department of environmental sciences to which also Prof.dr.ir. Rutgerd Boelens also belongs. Within this group investigation is ongoing on the social, political and ethical challenges in water management with a specific focus on Latin-America. In addition to that the knowledge base program 'Food security and Valuing water' works on the value of water developing concepts on how this should or could be implemented.

${ }^{16}$ National Geographic April 2010 


\section{Conclusions}

Currently the focus in The Netherlands is on mitigating the threats of water. For example intensive rain showers (leading to floods), salination of agricultural lands, rising sea water levels due to global warming as well as droughts in the summers. Water is seen as an essential but as a finite resource. The research and policy is largely linear (take-use/make-discard). In the food system analysis of how water and how water management contributes, in a long term, to a sustainable food system is still missing. Water is paradoxically approached by either a source for human consumption, as drinking water and for use of daily needs (SDG6), or as an essential part of nature (SDG14). There is a need for both an overarching view on water as the corner stone for every life on earth for human beings (food, drink, industry) as well as for nature. Food production affects both. It has a major impact on the supply of scarce fresh water as well affecting the nutrient supply within it. Rethinking the circular role of water within the entire ecosystem is needed. Focussing both on the large (natural) water cycles as well as the smaller (human use/industrial) water cycles. A starting point, will be, in order to address these issues, to recognize that water has a role of water within a circular food system.

In the Dutch minister Schouten's circular vision ('Kringlooplandbouw') on agriculture it was highlighted that the Netherlands should show leadership and export knowhow where relevant to other countries. "The Netherlands must retain a leading role in the innovation of production methods, both nationally and in global food markets. With our knowledge and products, we can be an example for other countries when it comes to efficient production of food in circular processes, thus preventing and repairing damage to the ecosystem (water, soil, air)."

Firstly the Ministry of Agriculture, Nature and Food quality's (LNV) request to review work being done at Wageningen University and Research (WUR) on the role of water within a circular food system has been in itself very valuable. At WUR a lot of research on water is taking place as well as a lot of "water for food" research (see for some examples annex 3). However not much research is taking place from a circular food system (resource security) perspective. Most of the existing work is research takes place within a linear system mindset without much emphasis on its circular use. Furthermore much of the research project are undertaken in isolation of each other without much opportunity to learn from each other.

Our second conclusion is that water in the LNV vision is addressed largely from risk mitigation or scarcity perspective. The opportunities that circular system thinking offers have not yet fully been explored nor the (nutrient) opportunities/trade-offs when for example water meets land and where fresh water touches salt water. Currently, these (large) system approaches for food production are under addressed or are standalone topics. A deepening of the policy as well as practical application of the 3R principles: Reuse, Reduce and Recycle, underlying circular food system thinking is, we feel, much needed. Ministries as well as other public bodies in the Netherlands involved in water management, for its many function, will need to work more closely, earlier in the design process to ensure that also food production, using valuable resources available, becomes more circular in The Netherlands in the future.

Clearly where water is used, and in what form (colour) with which nutrients, will have trade-offs elsewhere which is why the whole system should be analysed to avoid blind spots. Those trade-offs need to be made visible for policy to ensure The Netherlands transitions to water and nutrient policy that is robust, lasting and sustainable. While each water adaption at one part will affect the other part somewhere else in the entire ecosystem. If, in a transition towards a more sustainable society, this will change and water (a finite resource) will be (re)used in a much more efficient way, knowledge gaps and health risks appear. Research should focus on water's role in a complex system, which requires a multidisciplinary approach. WUR offers many of these disciplines by its five science groups in which departments of the university and research institutes are represented. However, in general it has been concluded that mutual collaboration between research departments and university is not ways the case but rather an exception. Within WUR and with other research institutes outside WUR, as projects are still being conducted separately or compartmentalized. Water's role in a circular food system could be explored, Water's role in a circular food system | 19 
but is not covered by WUR yet. As water is a crucial resource, and is under pressure from society, environment and economy, it's role in a circular food system should be more explicitly explored using the colours of water principles to help unravel the aspects of water. Both in big cycles as well as small.

To illustrate the differing roles by the water colours :

Whereas green (surface) water has a microbial activity, meteorological (white) water, but also spring water stream water and groundwater (terra) are pretty 'clean'. Microbial activity is related to nutrient availability, but could also imply a potential risk. If water is used for human consumption purposes, the microbial activity should be low and these sources would therefore need protection against contamination. White and terra are our most important natural resources is terms of drinking water and green as most important growth source for crop growth (see Figure 4 / A). With the downstream increasing microbial activity, opportunities and challenges have and will be found in green, turquoise and indigo water (Figure 4 / B). Microbial most rich water seems to be black water. Water mixed with solid or semisolid remains of digestion (Figure 4 / C). Which takes us to another interesting aspect of fresh water. Water as vehicle or source of nutrients. Feeding our soil and crops with black, grey or green water.
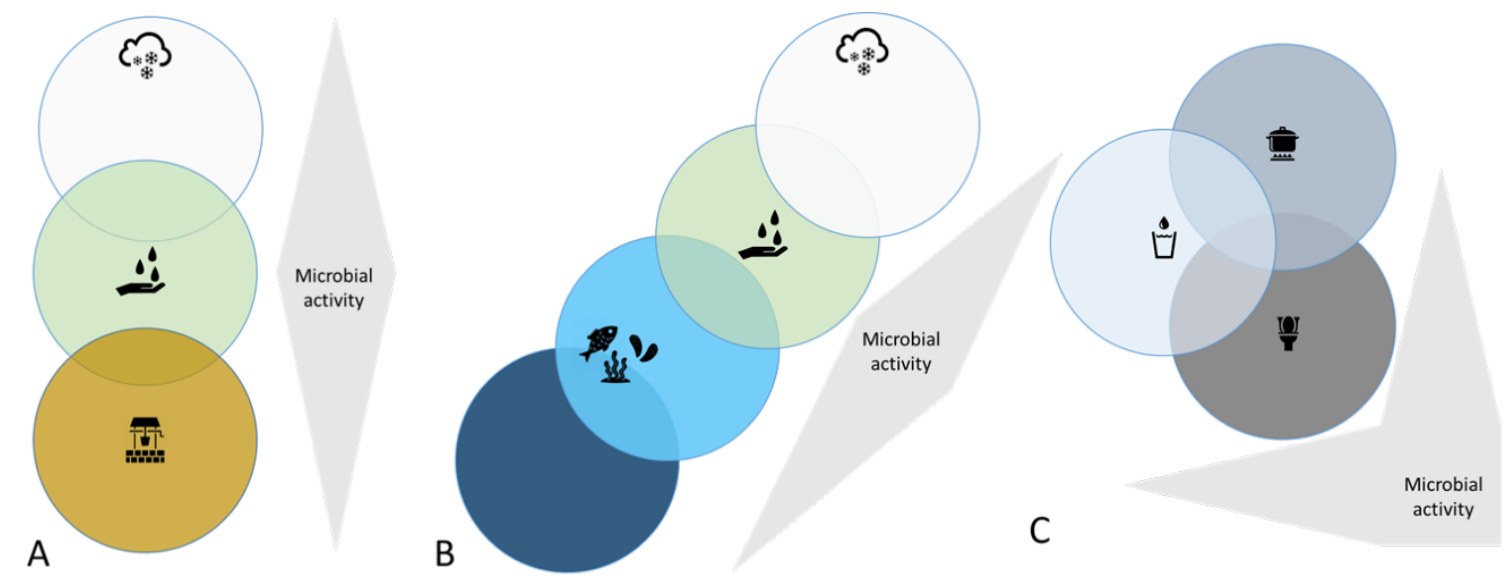

\section{FIGURE 4 WATER AS VEHICLE OR SOURCE FOR MICROBIAL ACTIVITY}

Colouring waters with different facets helps the exchange of views, but funded projects are needed to facilitate and stimulate the urgently asked multidisciplinary approach ('Finding Answers Together') in which all colours of water are taken into account. In this multidisciplinary approach all values (economic, social, environmental) should be taken in account. Opportunities in terms of resource security, source of nutrients and water's role in the entire ecosystem, without neglecting risk management and negative system shifts.

Practical action that can be undertaken in 2020 already:

At WUR:

1) To stimulate further dialog within WUR student teams can be asked to look into the role of water in a circular food system. A jury of diverse stakeholders (e.g. water treatment management, agricultural production organizations, marine production organizations, government and science) could evaluate the ideas of student teams.

2) The two knowledge basis programs ("water for food" and "circularity and climate") can design their programs in such a way that concepts on water in a circular food system (production) and food security (consumption) can be useful in NL as well as abroad. Stimulate the collaboration between WU and WR and between WR institutes. In each project should 
work at least different sciences groups, one or more departments of the university and at least different research institutes.

3) Collaboration by WUR with other knowledge institutes on this topic should be further explored (e.g. NIOZ, Deltares, TNO, HAS, AERES, HZ, Van Hall Larenstein etc.).

4) This basic concept (primer) of the colours of water, if found useful as a conversation tool, can be further developed (to scientifically supported analysis).

At Dutch government

1) Acknowledgement of the multiple roles of water in circular economy by the ministry of LNV.

2) Develop as Ministry LNV with Ministries I\&W as well as Rijkswaterstaat a collaborative team on a new "water for food" policy in order to transition jointly to a circular economy (society). Include water in a circular food system, invest in safety and health elements of water

3) Insights developed on this topic should be shared in multilateral fora to ensure that useful concepts are included in tenders of for example the International Financial Institutions.

Thinking and research on circular food systems, within a modern food system production, is quite new. Most of the research of the role of water within the food system at WUR is still linear. The question in itself however has been valuable as was the preparing this overview by us reaching out to all WUR departments. The reflection that it started will undoubtedly lead to research questions of value to the Netherlands in her food system transition as well as for work alongside our partners further afield. As LNV works closely together with I\&W on water and climate related issues so WUR needs to partner up also with Deltares. Water is the linking pin through land as well as the element that connects land to the sea and air. Using water (all of its colour's) in a more resource efficient way will help ensure that both future generations have access to it as well as a pave the way for a more equitable use now.

It is recommended to initiate a follow-up of this research that should provide answers to the remaining knowledge gaps:

- What are the quick wins to stimulate a circular food system in the Netherlands by circular water usages?

- Which trade-offs are in place in the water cycle if water is circular used for food production by reusing, recycling and reducing of the water colours and nutrients in the flows?

- Which best practice examples in the Netherlands of elsewhere could be inspiring to accomplish a circular food system (including agriculture)?

- Which action perspectives could be provided to farmers and other food producers if water is circularly used? In order to create high quality and productivity in the food production, in an economic efficient way and without compensating by harming the nature (e.g. biodiversity) and water ecosystem to a high extend.

The transition towards a sustainable eco- and food system, urgently requires to pinpoint the role of water in this system. The authors of this report hope to initiate this by 'colouring' water. Although not always scientifically substantiated, colouring helps with the exchanges of views and to clarify the role of water in a complex system as well as provide insights into several (new) facets. The authors have experienced this several times in many conversations held amongst themselves as well as with others and would like to emphasize the need to develop this concept of a system picture further.

Water's role in a circular food system | 21 


\section{Literature}

1. Hoekstra, A.Y., The water footprint assessment manual : setting the global standard. 2011, Earthscan: London [etc.].

2. Falkenmark, M. and J. Rockström, Balancing water for humans and nature: the new approach in ecohydrology. 2004, London ;: Earthscan.

3. European, C., Communication from the Commission to the European Parliament, the Council, the European Economic and Social Committee and the Committee of the Regions : a farm to Fork Strategy for a fair, healthy and environmentally-friendly food system. 2020, European Commission: Brussels.

4. Boer, I.J.M.d. and M.K.v. Ittersum, Circularity in agricultural production. 2018.

5. Krebs, C.J., Ecology : the experimental analysis of distribution and abundance. 6th ed. ed. 2009, San Francisco, CA: Pearson Benjamin Cummings.

6. Barnes, R.S.K. and R.N. Hughes, An introduction to marine ecology. 1999, Blackwell Science: Oxford [England] ;.

7. Broecker, W.S., Thermohaline circulation, the Achilles heel of our climate system: Will man-made CO2 upset the current balance? Science, 1997. 278 (5343): p. 1582-1588.

8. Clark, C.K.L. Ocean thermal energy conversion and open ocean mariculture: The prospect of Mainland-Taiwan collaborative research and development. Sustainable Environment Research, 2018. 28, 267-273 DOI: 10.1016/j.serj.2018.06.002.

9. Meer, J.v.d., Limits to marine food production. 2020.

10. Vos, A.d., et al., Crop salt tolerance under controlled field conditions in The Netherlands, based on trials conducted at Salt Farm Texel. 2016, Salt Farm Texel: Den Burg.

11. Hattum, T., et al., Towards Water Smart Cities : climate adaptation is a huge opportunity to improve the quality of life in cities. 2016, Wageningen University \& Research: Wageningen.

12. Balendonck, J., Slim omgaan met water en meststoffen door toepassing van sensoren: "More Crop per Drop". 2011.

13. Prins, H., et al., Damage to Dutch agricultural and horticultural crops as a result of the drought in 2018 : Extent of crop yield losses and mitigating and adaptive measures taken by farmers and growers. 2018.

14. Intergovernmental Panel on Climate, C., The ocean and cryosphere in a changing climate : summary for policymakers / IPCC Intergovernmental Panel on Climate Change. 2019, IPCC: [Place of publication not identified].

15. Meer, R.W.v.d., Watergebruik in de land- en tuinbouw 2017 en 2018. 2020, Wageningen Economic Research: Wageningen.

16. Druenen, R.v. and E. Vastrick Klimaatbuffer: effectief groen als richtlijn voor het ontwerpen van klimaatbestendige stad : 'richt steden in met effectief groen in plaats van alleen maar meer groen'. Stad + groen : vakblad over openbaar groen en het vergroenen van de buitenruimte 7 (2): 55 - 59, 2019.

17. Kabir, K.A., et al., Feeding fish or pond . . .? 2019, Wageningen University: Wageningen.

18. Hermsen, D., M.C.J.D. Verdegem, and J.A.J.P.d. Verreth, Nutritious ponds : valorising waste using natural production. 2020, Wageningen University: Wageningen.

19. Feachem, R.G., Sanitation and disease : health aspects of excreta and wastewater management. World Bank studies in water supply and sanitation ; 3. 1983, Chichester [West Sussex] ;: Published for the World Bank by Wiley.

20. Mekonnen, M.M. and A.Y. Hoekstra, The green, blue and grey water footprint of farm animals and animal products: volume 1: main report. 2010, UNESCO-IHE: Delft. 


\section{Justification}

Report C068/20 / DOI: 10.18174/527866

Project Number: BO-43-023.02-007

The scientific quality of this report has been peer reviewed by a colleague scientist and a member of the Management Team of Wageningen Marine Research

Approved: $\quad$ Marnix Poelman

Researcher

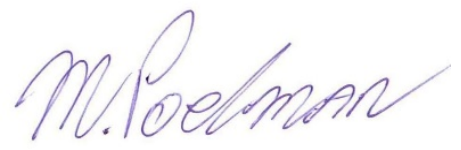

Date:

3 November 2020

Approved: Jakob Asjes

Manager Integration

Signature:

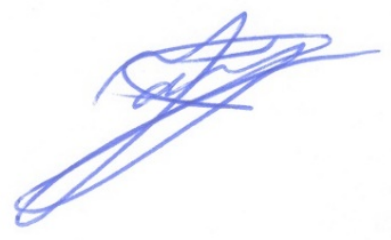

Date:

3 November 2020 


\section{Annex 1 | Benchmark Dutch Ministry of Agriculture, Nature and Food Quality linked to water}

The vision of minister Carola Schouten is not a blueprint however not without obligation either. It wishes it to function as a benchmark for national government policy, and will also help other decision-makers make their own choices. The factors to which policy intentions, plans, proposals and the like can be assessed are:

Do they

1. help to close cycles, to reduce emissions and to reduce biomass wastage throughout the food system?

2. contribute to sustainable fish stock management without damaging the natural environment?

3. strengthen the socio-economic position of the farmer in the supply chain?

4. contribute to the climate task for agriculture and land use?

5. enhance the appeal and vitality of the countryside and contribute to a thriving regional economy?

6. benefit ecosystems (water, soil, air), biodiversity and the natural value of the farming landscape?

7. consider animal welfare?

8. contribute to the recognition of the value of food and to strengthening the relationship between farmers and citizens?

9. strengthen the position of the Netherlands as a developer and exporter of integrated solutions for climate-smart and ecologically sustainable food systems?

\section{Assessment factors related to the biosphere are}

1. Helping to close cycles, reduce emissions and to reduce biomass wastage throughout the food system;

2. Contributing to sustainable fish stock management without damaging the natural environment;

4. Contribute to the climate task for agriculture and land use;

6. Benefit ecosystems (water, soil, air), biodiversity and the natural value of the farming landscape.

Of these two can be linked to water: \#2 fisheries without damaging the natural environment as well as \#6. "Benefit ecosystems (water, soil, air), biodiversity and the natural value of the farming landscape" 
Annex 2 | Hidden Water

Source: National Geographic April 2010

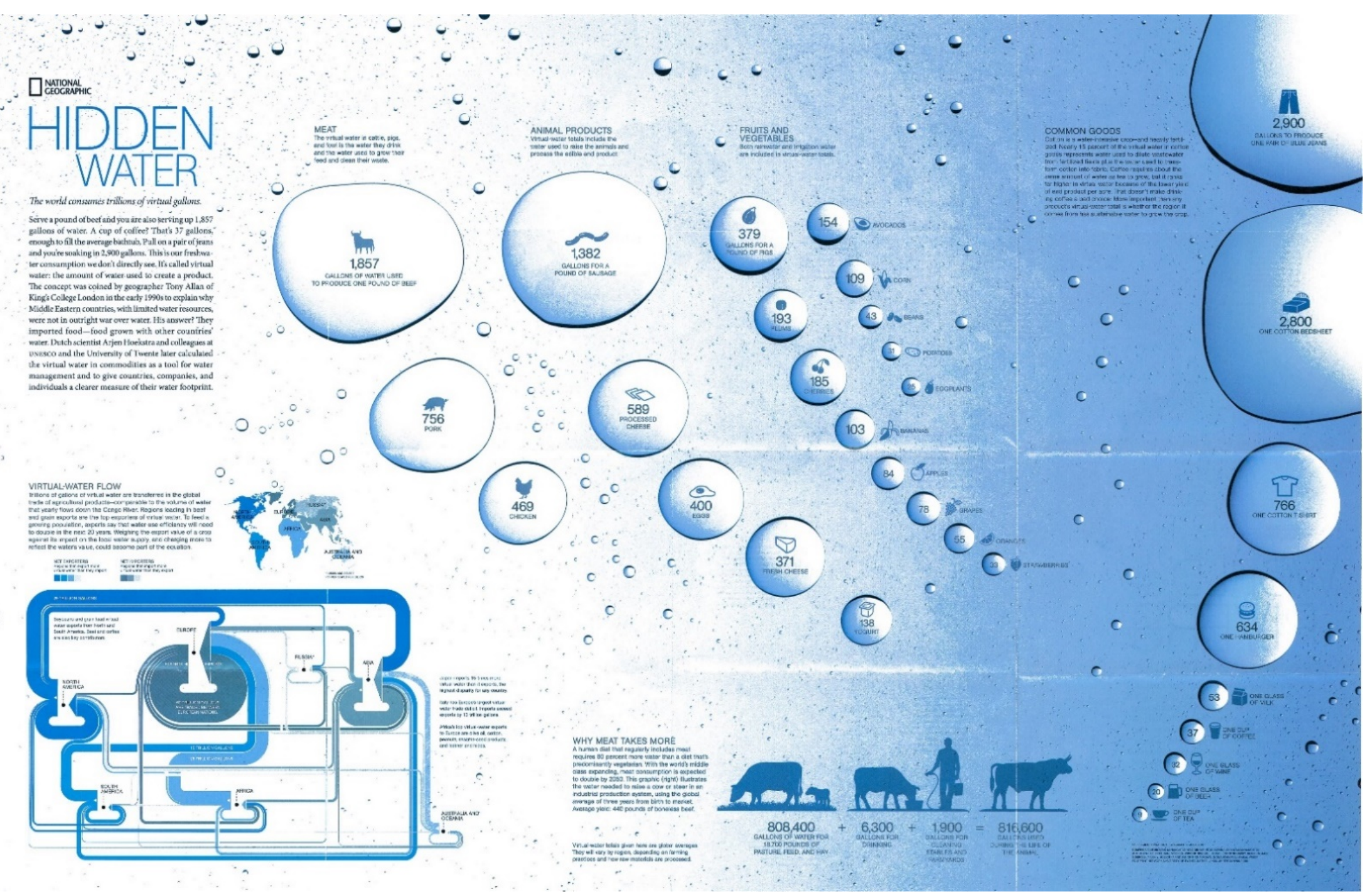




\section{Annex 3 | Water related projects identified at WUR}

Part A; List of the WUR-researchers encountered and their affiliations and the color to which their work relate to

\begin{tabular}{|c|c|c|c|c|c|c|c|c|c|c|c|c|c|c|c|c|}
\hline \multirow{2}{*}{$\begin{array}{l}\text { WU / } \\
\text { WR }\end{array}$} & \multirow{2}{*}{$\begin{array}{l}\text { DEP / } \\
\text { BU }\end{array}$} & \multirow{2}{*}{$\begin{array}{c}\text { Knowledge } \\
\text { unit }\end{array}$} & \multicolumn{2}{|c|}{ Coordinates Researchers } & \multirow{2}{*}{ Keywords research } & \multicolumn{8}{|c|}{ Water colours according to infographic } & \multicolumn{3}{|c|}{ Water flavours } \\
\hline & & & Name & Mail address & & Indigo & Turquoise & Green & Terra & White & Blue & Grey & Black & Salt & Brackish & Fresh \\
\hline WR & WBVR & ASG & Clazien de Vos & clazien.devos@wur.nl & \begin{tabular}{|l|} 
Risk assessment, Veterinary \\
epidemiology
\end{tabular} & & & & & & & & $x$ & & & $x$ \\
\hline WR & WBVR & ASG & Miriam Koene & miriam.koene@wur.nl & Bacteriology, Zoonoses & & & $x$ & & & $x$ & $x$ & & & & $x$ \\
\hline WR & WBVR & ASG & Wim van der Poel & wim.vanderpoel@wur.nl & Virology, epidemiology & & & $x$ & & & & $\mathrm{x}$ & $x$ & & & $x$ \\
\hline WR & WBVR & WOT & Kees Veldman & kees.veldman@wur.nl & Antibiotics Resistance in animals & & & & & & & & & & & $\mathrm{x}$ \\
\hline WR & WBVR & WOT & Manon Swanenburg & manon.swanenburg@wur.nl & Veterinary epidemiology & & & & & & & & $\mathrm{x}$ & & & $x$ \\
\hline WR & WCDI & SSG & Arend Jan van Bodegem & arendjan.vanbodegom@wur.nl & Competing claims on resources & & & $x$ & & $x$ & $x$ & & & & $x$ & $\mathrm{x}$ \\
\hline WR & WCDI & SSG & Marianne van Dorp & marianne.vandorp@wur.nl & $\begin{array}{l}\text { Food safety, combined crop and } \\
\text { fish cultivation }\end{array}$ & & & & & & $\mathrm{x}$ & $\mathrm{x}$ & & & & $\mathrm{x}$ \\
\hline WR & WEcR & SSG & Hans van Oostenbrugge & hans.van.oostenbrugge@wur.nl & $\begin{array}{l}\text { Offshore multi-use platforms for } \\
\text { aquaculture }\end{array}$ & $x$ & $\mathrm{x}$ & & & & & & & $\mathrm{x}$ & & \\
\hline WR & WEcR & SSG & Marga Hoogeveen & marga.hoogeveen@wur.nl & $\begin{array}{l}\text { Derogation, monitoring manure } \\
\text { policy and water quality }\end{array}$ & & & $x$ & & $x$ & $\mathrm{x}$ & & & & & $\mathrm{x}$ \\
\hline WR & WEcR & SSG & Stijn Reinhard & stijn.reinhard@wur.nl & $\begin{array}{l}\text { Water management, living labs; } \\
\text { Green Water Credits }\end{array}$ & & $x$ & $x$ & & $\mathrm{x}$ & $\mathrm{x}$ & & & & $x$ & $x$ \\
\hline WR & WEcR & SSG & Vincent Linderhof & vincent.linderhof@wur.nl & Water availability, food production & & $x$ & $x$ & & $x$ & $\mathrm{x}$ & $x$ & & & $x$ & $x$ \\
\hline WR & WEnR & ESG & Arjan Budding & arjan.budding@wur.nl & Sustainable water management & & & $x$ & & & $x$ & & & & & $x$ \\
\hline WR & WEnR & ESG & $\begin{array}{l}\text { Catharien Terwisscha van } \\
\text { Scheltinga }\end{array}$ & catharien.terwisscha@wur.nl & Water and Food & & & $x$ & & $x$ & & & & & & $x$ \\
\hline WR & WEnR & ESG & Francine Loos & francine.loos@wur.nl & $\begin{array}{l}\text { Water purification marsh for } \\
\text { Heineken }\end{array}$ & & & & & & & $\mathrm{x}$ & & & & $\mathrm{x}$ \\
\hline WR & WEnR & ESG & Hester Biemans & hester.biemans@wur.nl & Water and Food & & & $\mathrm{x}$ & & $\mathrm{x}$ & & & & & & $x$ \\
\hline WR & WEnR & ESG & Inge Regelink & inge.regelink@wur.nl & $\begin{array}{l}\text { Nutrient retrieving and } \\
\text { assessment i.r.t. agronomical } \\
\text { effectivity and environmental } \\
\text { quality. Valorisation humic acids } \\
\text { from waste flows }\end{array}$ & & & & & & $\mathrm{x}$ & $\mathrm{x}$ & $\mathrm{x}$ & & & $x$ \\
\hline WR & WEnR & ESG & Jeroen Veraart & jeroen.veraart@wur.nl & $\begin{array}{l}\text { Climate change, water } \\
\text { management and research } \\
\text { strategy }\end{array}$ & & $x$ & $x$ & & & & & & $x$ & $x$ & $x$ \\
\hline
\end{tabular}

Water's role in a circular food system | 26 


\begin{tabular}{|c|c|c|c|c|c|c|c|c|c|c|c|c|c|c|c|c|}
\hline WR & WEnR & ESG & Oscar Schoumans & oscar.schoumans@wur.nl & $\begin{array}{l}\text { Added value from wastewater } \\
\text { (animal excretion) and } \\
\text { development of economical } \\
\text { feasible business case }\end{array}$ & & & & & & & $\mathrm{x}$ & $\mathrm{x}$ & & & $\mathrm{x}$ \\
\hline WR & WEnR & ESG & Piet Verdonschot & piet.verdonschot@wur.nl & $\begin{array}{l}\text { AquaFarm: Valuable products } \\
\text { from wastewater }\end{array}$ & & & & & & & $x$ & $\mathrm{x}$ & & & $\mathrm{x}$ \\
\hline WR & WEnR & ESG & Saskia Visser & saskia.visser@wur.nl & $\begin{array}{l}\text { Circular and climate neutral water } \\
\text { (usage) }\end{array}$ & & & $x$ & & $\mathrm{x}$ & $x$ & $\mathrm{x}$ & & & $x$ & $x$ \\
\hline WR & WEnR & ESG & Wieger Wamelink & wieger.wamelink@wur.nl & $\begin{array}{l}\text { Water purification marsh for } \\
\text { Heineken }\end{array}$ & & & & & & & $\mathrm{x}$ & & & & $x$ \\
\hline WR & WFBR & AFSG & Irma Steemers-Rijkse & irma.steemers-rijkse@wur.nl & $\begin{array}{l}\text { Water treatment \& technology; } \\
\text { Purification, reclaim substances; } \\
\text { close water circle }\end{array}$ & & & $x$ & & $\mathrm{x}$ & $\mathrm{x}$ & $\mathrm{x}$ & $\mathrm{x}$ & & $\mathrm{x}$ & $x$ \\
\hline WR & WFBR & AFSG & Raymond Creusen & raymond.creusen@wur.nl & $\begin{array}{l}\text { Economical and ecological water } \\
\text { usage }\end{array}$ & & & $x$ & & $\mathrm{x}$ & & $\mathrm{x}$ & & & & \\
\hline WR & WFBR & AFSG & Wilfred Appelman & wilfred.appelman@wur.nl & $\begin{array}{l}\text { Water separation technologies, } \\
\text { water purification }\end{array}$ & & & & & & & $x$ & $\mathrm{x}$ & & & $x$ \\
\hline WR & WFSR & WOT & Arjen Gerssen & arjen.gerssen@wur.nl & $\begin{array}{l}\text { Analyses on phytotoxins in algae } \\
\text { or algae products, surface water } \\
\text { and irrigation and transmission of } \\
\text { toxins to vegetables and fruit }\end{array}$ & $x$ & $\mathrm{x}$ & $\mathrm{x}$ & $\mathrm{x}$ & & $\mathrm{x}$ & & & $\mathrm{x}$ & $\mathrm{x}$ & $\mathrm{x}$ \\
\hline WR & WFSR & WOT & Bjorn Berendsen & bjorn.berendsen@wur.nl & $\begin{array}{l}\text { Research on residues of veterinary } \\
\text { medicines and hormones }\end{array}$ & & & $x$ & & & $\mathrm{x}$ & $\mathrm{x}$ & & & & \\
\hline WR & WFSR & WOT & Esther van Asselt & esther.vanasselt@wur.nl & $\begin{array}{l}\text { research on disinfection } \\
\text { technologies in irrigation water } \\
\text { and washing water at vegetable } \\
\text { cutting companies }\end{array}$ & & & & & & $\mathrm{x}$ & $\mathrm{x}$ & & & & \\
\hline WR & WFSR & WOT & Jennifer Banach & jen.banach@wur.nl & $\begin{array}{l}\text { Research on chemical risks (heavy } \\
\text { metals) in seaweed also in relation } \\
\text { to water. Research on the effect of } \\
\text { disinfectants on pathogens in } \\
\text { washing water }\end{array}$ & & & & & & & & & & & \\
\hline WR & WFSR & WOT & Milou van de Schans & milou.vandeschans@wur.nl & $\begin{array}{l}\text { Research on residues of veterinary } \\
\text { medicines }\end{array}$ & & & $\mathrm{x}$ & & & $\mathrm{x}$ & $\mathrm{x}$ & & & & \\
\hline WR & WFSR & WOT & Siebren van Tuinen & siebren.vantuinen@wur.nl & $\begin{array}{l}\text { Research on chemical risks (heavy } \\
\text { metals) in seaweed also in relation } \\
\text { to water }\end{array}$ & & $\mathrm{x}$ & & & & & & & $\mathrm{x}$ & $\mathrm{x}$ & \\
\hline WR & WFSR & WOT & Stefan van Leeuwen & stefan.vanleeuwen@wur.nl & $\begin{array}{l}\text { Analysis on PFAS and other } \\
\text { contaminations of surface water, } \\
\text { waste water and potable water } \\
\text { and the accumulation of these in } \\
\text { fish }\end{array}$ & & & $\mathrm{x}$ & & & $\mathrm{x}$ & $\mathrm{x}$ & & & & \\
\hline
\end{tabular}

Water's role in a circular food system | 27 


\begin{tabular}{|c|c|c|c|c|c|c|c|c|c|c|c|c|c|c|c|}
\hline WR & WLR & ASG & Charlotte Verburg & charlotte.verburg@wur.nl & Sustainable livestock farming & & & & & $x$ & & & & & \\
\hline WR & WLR & ASG & Idse Hoving & idse.hoving@wur.nl & Dairy farms & & & $x$ & & $\mathrm{x}$ & & & & & \\
\hline WR & WLR & ASG & Luuk Gollenbeek & luuk.gollenbeek@wur.nl & \begin{tabular}{|l} 
Manure valuing, soil \\
improvement, increase water \\
storage capacity
\end{tabular} & & & $\mathrm{x}$ & & $\mathrm{x}$ & & & & & $x$ \\
\hline WR & WLR & ASG & Marion de Vries & marion.devries@wur.nl & $\begin{array}{l}\text { Climate adaptation and mitigation } \\
\text { in dairy farms }\end{array}$ & & & $\mathrm{x}$ & & $x$ & & & & & $x$ \\
\hline WR & WLR & ASG & Michel de Haan & Michel.dehaan@wur.nl & Water usage on (dairy) farms & & & $x$ & & $\mathrm{x}$ & & & & & $\mathrm{x}$ \\
\hline WR & WMR & ASG & Dolfi Debrot & dolfi.debrot@wur.nl & $\begin{array}{l}\text { Sustainable food production in } \\
\text { marine systems }\end{array}$ & $x$ & $x$ & & & & & & $x$ & $\mathrm{x}$ & \\
\hline WR & WMR & ASG & Henrice Jansen & henrice.jansen@wur.nl & \begin{tabular}{l|} 
Implementation of new \\
technologies for food production
\end{tabular} & & $x$ & & & & $x$ & & $x$ & $\mathrm{x}$ & \\
\hline WR & WMR & ASG & Jaap van der Meer & jaap.vandermeer@wur.nl & $\begin{array}{l}\text { Nutrient dynamics and transition } \\
\text { in marine ecosystems }\end{array}$ & $x$ & $x$ & & & & & & $x$ & $x$ & \\
\hline WR & WMR & ASG & Marnix Poelman & marnix.poelman@wur.nl & $\begin{array}{l}\text { Proteins from saline residual } \\
\text { currents, low trophic food } \\
\text { production in marine systems }\end{array}$ & $x$ & $x$ & & & & $x$ & & $x$ & $\mathrm{x}$ & \\
\hline WR & WMR & ASG & Reinier Nauta & reinier.nauta@wur.nl & $\begin{array}{l}\text { Role of seaweed in a circular } \\
\text { system }\end{array}$ & $x$ & $x$ & & & & & & $x$ & $x$ & \\
\hline WR & WPR & PSG & Caroline van der Salm & caroline.vandersalm@wur.nl & Water and nutrient efficiency & & & $x$ & $\mathrm{x}$ & $x$ & $x$ & & & & $x$ \\
\hline WR & WPR & PSG & Corne Kempenaar & corne.kempenaar@wur.nl & $\begin{array}{l}\text { Value creation in the potatoes } \\
\text { chain in India and Ethiopia }\end{array}$ & & & $\mathrm{x}$ & $\mathrm{x}$ & $\mathrm{x}$ & $x$ & & & & $\mathrm{x}$ \\
\hline WR & WPR & PSG & Ellen Beerling & ellen.beerling@wur.nl & Zero emission cultivation & & & $x$ & $x$ & & $x$ & & & & $\mathrm{x}$ \\
\hline WR & WPR & PSG & Rommie van der Weide & rommie.vanderweide@wur.nl & $\begin{array}{l}\text { Cultivation and usage of aquatic } \\
\text { biomass; Reuse of waste water; } \\
\text { sustainable energy and green } \\
\text { resources; climate adaptive soils }\end{array}$ & & $x$ & $x$ & & & $x$ & $x$ & $x$ & $\mathrm{x}$ & $\mathrm{x}$ \\
\hline WR & WPR & PSG & Wouter Verkerke & wouter.verkerke@wur.nl & Circular greenhouse horticulture & & & & $x$ & & $x$ & & & & $x$ \\
\hline WU & DEP & ASG & Johan Verreth & johan.verreth@wur.nl & $\begin{array}{l}\text { Nutrient dynamics in aquaculture } \\
\text { and fish cultivation. Emeritus } \\
\text { chairholder Aquaculture \& } \\
\text { Fisheries } \\
\end{array}$ & & $x$ & $\mathrm{x}$ & & & $\mathrm{x}$ & & & $\mathrm{x}$ & $\mathrm{x}$ \\
\hline WU & DEP & AFSG & Cees Buisman & cees.buisman@wur.nl & $\begin{array}{l}\text { Chairholder Biological circular } \\
\text { technologies. Reconcentration of } \\
\text { diluted currents for reusage of } \\
\text { content components } \\
\end{array}$ & & & $\mathrm{x}$ & & $\mathrm{x}$ & $x$ & & $x$ & $\mathrm{x}$ & $x$ \\
\hline WU & DEP & AFSG & Huub Rijnaarts & huub.rijnaarts@wur.nl & \begin{tabular}{|l|} 
Chairholder Environmental \\
technology
\end{tabular} & & & $x$ & & $\mathrm{x}$ & $x$ & & $x$ & $x$ & $\mathrm{x}$ \\
\hline WU & DEP & AFSG & Rene Wijffels & rene.wijffels@wur.nl & \begin{tabular}{|l} 
Chairholder Bioprocess \\
engineering
\end{tabular} & & $\mathrm{x}$ & $\mathrm{x}$ & & $x$ & $x$ & & $x$ & $\mathrm{x}$ & $\mathrm{x}$ \\
\hline
\end{tabular}

Water's role in a circular food system | 28 


\begin{tabular}{|c|c|c|c|c|c|c|c|c|c|c|c|c|c|c|c|c|}
\hline WU & DEP & ASG & Geert Wiegertjes & geert.wiegertjes@wur.nl & $\begin{array}{l}\text { Chairholder Aquaculture \& } \\
\text { Fisheries. }\end{array}$ & |x & $x$ & $x$ & & & & & & $x$ & $x$ & $x$ \\
\hline WU & DEP & ESG & Bart Koelmans & bart.koelmans@wur.nl & \begin{tabular}{|l|} 
Chairholder Ecology and water \\
quality management
\end{tabular} & $x$ & $x$ & $x$ & & & $x$ & & & $x$ & $x$ & $x$ \\
\hline WU & DEP & ESG & Carolien Kroeze & carolien.kroeze@wur.nl & $\begin{array}{l}\text { Chairholder Water systems and } \\
\text { Global change Group }\end{array}$ & $x$ & $x$ & $x$ & $x$ & $x$ & $x$ & $x$ & $x$ & $x$ & $x$ & $x$ \\
\hline WU & DEP & ESG & Jordi Vila-Guerau de Arellano & jordi.vila@wur.nl & $\begin{array}{l}\text { Chairholder meteorology and air } \\
\text { quality }\end{array}$ & & & $x$ & & $x$ & & & & & & $x$ \\
\hline WU & DEP & ESG & Petra Hellegers & petra.hellegers@wur.nl & $\begin{array}{l}\text { Chairholder Water resources } \\
\text { management }\end{array}$ & & $x$ & $x$ & & $x$ & $x$ & & & & $x$ & $x$ \\
\hline WU & DEP & ESG & Rachel Creamer & rachel.creamer@wur.nl & $\begin{array}{l}\text { Chairholder soil biology; the soil as } \\
\text { key for sustainable (agricultural) } \\
\text { ecosystems }\end{array}$ & & & $x$ & $x$ & & & & & & $x$ & $x$ \\
\hline WU & DEP & ESG & Ton Hoitink & ton.hoitink@wur.nl & $\begin{array}{l}\text { Chairholder Hydrology and } \\
\text { quantitative water management }\end{array}$ & & $x$ & $x$ & & $x$ & & & & $x$ & $x$ & $x$ \\
\hline WU & DEP & PSG & Ken Giller & ken.giller@wur.nl & $\begin{array}{l}\text { Chairholder Plant production } \\
\text { Systems group }\end{array}$ & & & $x$ & $x$ & & $x$ & & & & $x$ & $x$ \\
\hline WU & DEP & PSG & Rogier Schulte & rogier.schulte@wur.nl & $\begin{array}{l}\text { Chairholder Farming systems } \\
\text { Ecology Group }\end{array}$ & & & $x$ & $x$ & $x$ & & & & & & $x$ \\
\hline WU & DEP & SSG & Han Wiskerke & han.wiskerke@wur.nl & $\begin{array}{l}\text { Rural Sociology Group. Short } \\
\text { chains and closing circular systems } \\
\text { (water and nutrients), } \\
\text { multifunctional usage of space. } \\
\text { Ecosystem services in perspective } \\
\text { of water storage and } \\
\text { management. } \\
\end{array}$ & & & $x$ & & & $x$ & $x$ & & & & $x$ \\
\hline WUR & N/A & N/A & N/A & N/A & $\begin{array}{l}\text { Community of Practice; Salt } \\
\text { tolerance, collaboration, expert } \\
\text { table }\end{array}$ & & $x$ & $x$ & & & & $x$ & & $x$ & $x$ & $x$ \\
\hline WUR & $\mathrm{N} / \mathrm{A}$ & N/A & N/A & N/A & $\begin{array}{l}\text { Research theme 'Circular } \\
\text { Economy' }\end{array}$ & & & $\mathrm{x}$ & $x$ & $x$ & $x$ & & & & & $x$ \\
\hline
\end{tabular}


Part B; List of the WUR-researchers encountered with their relevant research projects

\begin{tabular}{|c|c|c|c|c|c|c|c|}
\hline \multirow{2}{*}{$\begin{array}{l}\text { WU / } \\
\text { WR }\end{array}$} & \multirow{2}{*}{$\begin{array}{l}\text { DEP / } \\
\text { BU }\end{array}$} & \multirow{2}{*}{$\begin{array}{l}\text { Knowledge } \\
\text { unit }\end{array}$} & \multicolumn{2}{|c|}{ Coordinates Researchers } & \multirow{2}{*}{ Relevant projects / content } & \multirow{2}{*}{\multicolumn{2}{|c|}{ Hyperlinks (if available) }} \\
\hline & & & Name & Mail address & & & \\
\hline WR & WBVR & ASG & Clazien de Vos & clazien.devos@wur.nl & $\begin{array}{l}\text { Risk assessment for farm animals } \\
\text { by application of animal viruses } \\
\text { for human cancer therapy? }\end{array}$ & & \\
\hline WR & WBVR & ASG & Miriam Koene & miriam.koene@wur.nl & $\begin{array}{l}\text { PPS- Controlling Campylobacter in } \\
\text { the poultry sector }\end{array}$ & $\begin{array}{l}\text { https://www.wur.nl/nl/Onderzoek- } \\
\text { Resultaten/Onderzoeksprojecten- } \\
\text { LNV/Expertisegebieden/kennisonline/Campylobacter- } \\
\text { de-baas-1.htm }\end{array}$ & \\
\hline WR & WBVR & ASG & $\begin{array}{l}\text { Wim van der } \\
\text { Poel }\end{array}$ & wim.vanderpoel@wur.nl & $\begin{array}{l}\text { Virus detection; Water reusage in } \\
\text { e.g. abattoirs }\end{array}$ & \begin{tabular}{|l|} 
https://www.wur.nl/en/Research- \\
Results/kennisonline/Emerging-health-risks-and- \\
emerging-food-safety-risks.htm \\
\end{tabular} & \\
\hline WR & WBVR & WOT & Kees Veldman & kees.veldman@wur.nl & & & \\
\hline WR & WBVR & WOT & $\begin{array}{l}\text { Manon } \\
\text { Swanenburg }\end{array}$ & manon.swanenburg@wur.nl & $\begin{array}{l}\text { Risk analysis on the introduction } \\
\text { of carbapenem resistance in the } \\
\text { Dutch animal population }\end{array}$ & & \\
\hline WR & WCDI & SSG & $\begin{array}{l}\text { Arend Jan van } \\
\text { Bodegem }\end{array}$ & arendjan.vanbodegom@wur.nl & $\begin{array}{l}\text { Circular agriculture in low and } \\
\text { middle income countries. }\end{array}$ & $\begin{array}{l}\text { https://www.wur.nl/en/show/Concurrerende-Claims- } \\
\text { op-natuurlijke-hulpbronnen.htm }\end{array}$ & \\
\hline WR & WCDI & SSG & $\begin{array}{l}\text { Marianne van } \\
\text { Dorp }\end{array}$ & marianne.vandorp@wur.nl & Sustainable food security & & \\
\hline WR & WEcR & SSG & $\begin{array}{l}\text { Hans van } \\
\text { Oostenbrugge }\end{array}$ & hans.van.oostenbrugge@wur.nl & $\begin{array}{l}\text { MERMAID - Innovative Multi- } \\
\text { purpose off-shore platforms }\end{array}$ & https://www.wur.nl/en/show/mermaid.htm & \\
\hline WR & WEcR & SSG & $\begin{array}{l}\text { Marga } \\
\text { Hoogeveen }\end{array}$ & marga.hoogeveen@wur.nl & $\begin{array}{l}\text { National measurement network } \\
\text { on the effects of the manure } \\
\text { policy }\end{array}$ & $\begin{array}{l}\text { https://www.wur.nl/nl/Onderzoek- } \\
\text { Resultaten/Onderzoeksinstituten/Economic- } \\
\text { Research/Themas/Monitoring- } \\
\text { duurzaamheid/Landelijk-Meetnet-effecten- } \\
\text { Mestbeleid.htm }\end{array}$ & $\begin{array}{l}\text { https://www.wur.nl/en/newsarticle/ } \\
\text { ffect-van-derogatie-op-Nederlandse- } \\
\text { waterkwaliteit.htm }\end{array}$ \\
\hline
\end{tabular}

Water's role in a circular food system | 30 


\begin{tabular}{|c|c|c|c|c|c|c|c|}
\hline WR & WEcR & SSG & Stijn Reinhard & stijn.reinhard@wur.nl & $\begin{array}{l}\text { Water Management Knowledge } \\
\text { and Innovation Program (WMKIP), } \\
\text { Bangladesh I Compensation for } \\
\text { better water and soil management } \\
\text { also rewarding for food supply }\end{array}$ & $\begin{array}{l}\text { https://www.wur.nl/en/Research- } \\
\text { Results/kennisonline/Food-Water-Nexus-1.htm }\end{array}$ & $\begin{array}{l}\text { https://www.wur.nl/en/article/Manag } \\
\text { ing-water-together-1.htm }\end{array}$ \\
\hline WR & WEcR & SSG & $\begin{array}{l}\text { Vincent } \\
\text { Linderhof }\end{array}$ & vincent.linderhof@wur.nl & $\begin{array}{l}\text { KB Water availability (quantity and } \\
\text { quality) }\end{array}$ & $\begin{array}{l}\text { https://www.wur.nl/en/Research- } \\
\text { Results/kennisonline/Waterbeschikbaarheid- } \\
\text { kwantiteit-en-kwaliteit.htm }\end{array}$ & \\
\hline WR & WEnR & ESG & Arjan Budding & arjan.budding@wur.nl & $\begin{array}{l}\text { Program Sustainable water } \\
\text { management (program leader) }\end{array}$ & $\begin{array}{l}\text { https://www.wur.nl/en/Research-Results/Research- } \\
\text { Institutes/Environmental- } \\
\text { Research/Programmes/Sustainable-Water- } \\
\text { Management.htm }\end{array}$ & \\
\hline WR & WEnR & ESG & \begin{tabular}{|l|} 
Catharien \\
Terwisscha van \\
Scheltinga \\
\end{tabular} & catharien.terwisscha@wur.nl & \begin{tabular}{|l|} 
Climate change, education, \\
irrigation and drainage, water \\
management, capacity building \\
\end{tabular} & & \\
\hline WR & WEnR & ESG & Francine Loos & francine.loos@wur.nl & $\begin{array}{l}\text { How can a marsh area be } \\
\text { developed as a nature parc with } \\
\text { increase biodiversity and natural } \\
\text { filtering by plants, with the use of } \\
\text { waste water from a beer. }\end{array}$ & $\begin{array}{l}\text { https://www.wur.nl/en/project/A-water-purification- } \\
\text { marsh-for-Heineken-and-the-region.htm }\end{array}$ & \\
\hline WR & WEnR & ESG & Hester Biemans & hester.biemans@wur.nl & Hi-aware; Sustaindus & $\begin{array}{l}\text { https://www.wur.nl/en/project/The-Himalayan- } \\
\text { Adaptation-Water-and-Resilience-HI-AWARE.htm }\end{array}$ & $\begin{array}{l}\text { https://www.wur.nl/nl/Onderzoek- } \\
\text { Resultaten/Onderzoeksinstituten/Envi } \\
\text { ronmental-Research/show- } \\
\text { wenr/HighNoon-adaptatie-aan- } \\
\text { veranderende-waterbeschikbaarheid- } \\
\text { in-Noord-India.htm }\end{array}$ \\
\hline WR & WEnR & ESG & Inge Regelink & inge.regelink@wur.nl & $\begin{array}{l}\text { Valorisation of humic acids and } \\
\text { iron sludge from potable water; } \\
\text { Humic acids derived from residual } \\
\text { currents and manure }\end{array}$ & $\begin{array}{l}\text { https://www.wur.nl/nl/project/Humuszuren-uit- } \\
\text { afvalstromen-en-mest-Een-waardevolle- } \\
\text { biostimulant.htm }\end{array}$ & $\begin{array}{l}\text { https://www.wur.nl/nl/project/Sludge } \\
\text { 2Soil.htm }\end{array}$ \\
\hline WR & WEnR & ESG & Jeroen Veraart & jeroen.veraart@wur.nl & $\begin{array}{l}\text { Nature as buffer against climate } \\
\text { change; Wet nature in the } \\
\text { northern parts of The } \\
\text { Netherlands. }\end{array}$ & $\begin{array}{l}\text { https://www.wur.nl/nl/Onderzoek- } \\
\text { Resultaten/Onderzoeksprojecten- } \\
\text { LNV/Expertisegebieden/kennisonline/Natte-Natuur- } \\
\text { in-Noord-Nederland.htm }\end{array}$ & \\
\hline
\end{tabular}

Water's role in a circular food system | 31 


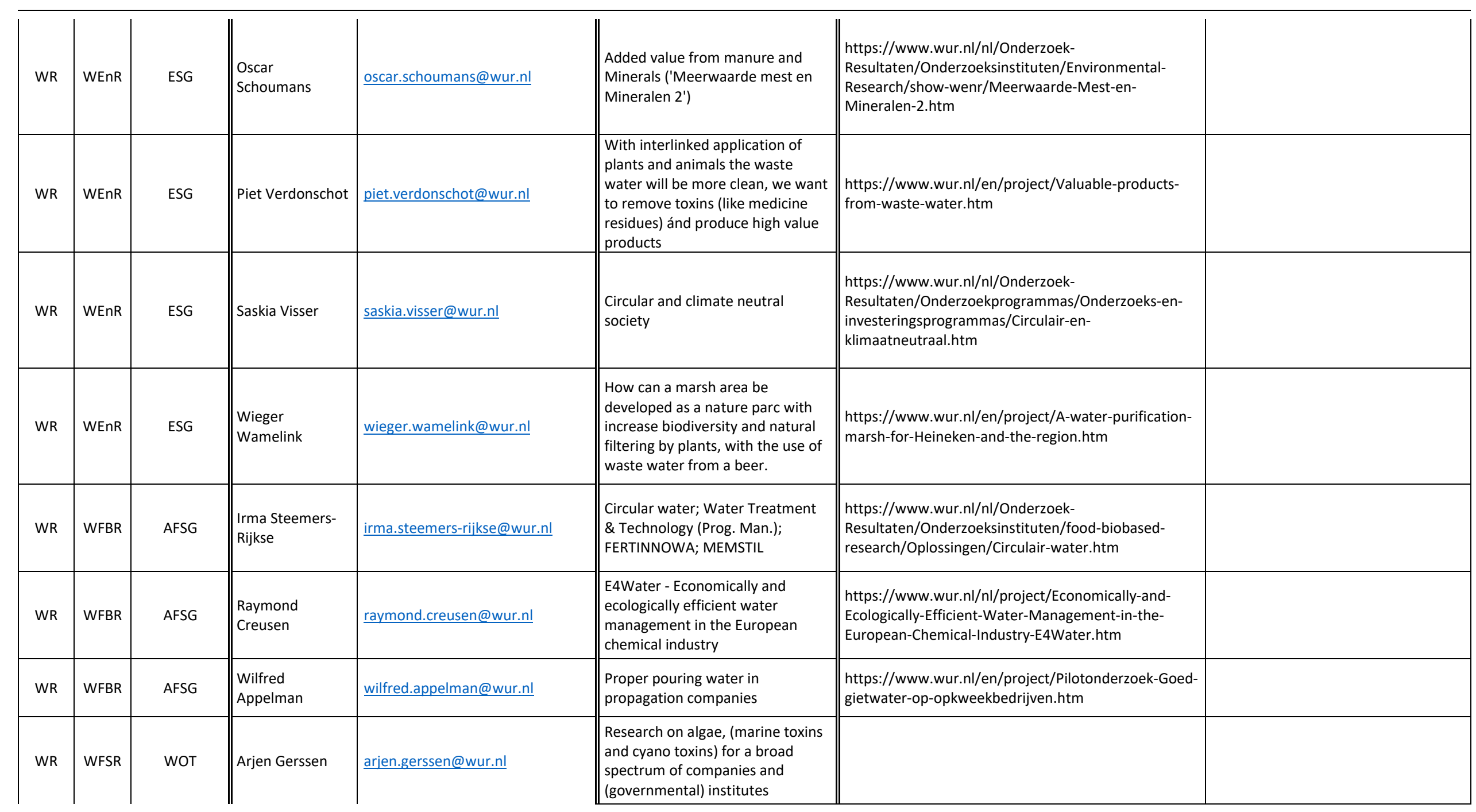

Water's role in a circular food system | 32 


\begin{tabular}{|c|c|c|c|c|c|c|c|}
\hline WR & WFSR & WOT & Bjorn Berendsen & bjorn.berendsen@wur.nl & $\begin{array}{l}\text { Surveys third parties (WEnR, water } \\
\text { authorities, RIVM); Water related } \\
\text { research with the KB-project } \\
\text { 'Connected circularity flagship 2'; } \\
\text { Survey to potable water research } \\
\text { for animals within the WOT- } \\
\text { research on antibiotics. }\end{array}$ & $\begin{array}{l}\text { https://www.wur.nl/nl/Onderzoek- } \\
\text { Resultaten/Onderzoeksprojecten- } \\
\text { LNV/Expertisegebieden/kennisonline/Flagship-2- } \\
\text { Ensuring-quality-and-safety.htm }\end{array}$ & \\
\hline WR & WFSR & WOT & Esther van Asselt & esther.vanasselt@wur.nl & PPS-project Safe and Save Water & $\begin{array}{l}\text { https://www.wur.nl/nl/Onderzoek- } \\
\text { Resultaten/Onderzoeksprojecten- } \\
\text { LNV/Expertisegebieden/kennisonline/Safe-and-save- } \\
\text { water-in-the-fresh-produce-supply-chain.htm }\end{array}$ & \\
\hline WR & WFSR & WOT & Jennifer Banach & jen.banach@wur.nl & $\begin{array}{l}\text { Projects for NVWA, SOMOS (i.e. } \\
\text { food safety); PPS-project } \\
\text { Microbiology in greenhouse } \\
\text { horticulture }\end{array}$ & & \\
\hline WR & WFSR & WOT & $\begin{array}{l}\text { Milou van de } \\
\text { Schans }\end{array}$ & milou.vandeschans@wur.nl & $\begin{array}{l}\text { Surveys third parties (WEnR, water } \\
\text { authorities, RIVM); Water related } \\
\text { research with the KB-project } \\
\text { 'Connected circularity flagship 2'; } \\
\text { Survey to potable water research } \\
\text { for animals within the WOT- } \\
\text { research on antibiotics }\end{array}$ & & \\
\hline WR & WFSR & WOT & $\begin{array}{l}\text { Siebren van } \\
\text { Tuinen }\end{array}$ & siebren.vantuinen@wur.nl & $\begin{array}{l}\text { Projects for multiple (semi) } \\
\text { governmental and private } \\
\text { organisations; European norm } \\
\text { commission CEN-TC } 454\end{array}$ & & \\
\hline WR & WFSR & WOT & $\begin{array}{l}\text { Stefan van } \\
\text { Leeuwen }\end{array}$ & stefan.vanleeuwen@wur.nl & $\begin{array}{l}\text { Surveys for third parties and } \\
\text { methodology development within } \\
\text { KB-project 'Bio assays and } \\
\text { analytics' }\end{array}$ & & \\
\hline
\end{tabular}




\begin{tabular}{|c|c|c|c|c|c|c|c|}
\hline WR & WLR & ASG & $\begin{array}{l}\text { Charlotte } \\
\text { Verburg }\end{array}$ & charlotte.verburg@wur.nl & $\begin{array}{l}\text { Livestock farming in delta's under } \\
\text { pressure; Circularity Index } \\
\text { ('Kringloopwijzer') }\end{array}$ & $\begin{array}{l}\text { https://www.wur.nl/nl/Onderzoek- } \\
\text { Resultaten/Onderzoeksprojecten- } \\
\text { LNV/Expertisegebieden/kennisonline/Possibilities-for- } \\
\text { sustainable-climate-resilient-livestock-farming-in- } \\
\text { Vietnamese-deltas-under-pressure-.htm }\end{array}$ & \\
\hline WR & WLR & ASG & Idse Hoving & idse.hoving@wur.nl & $\begin{array}{l}\text { Company water index (dairy } \\
\text { farms); Wise with water damage } \\
\text { ('Wijs met Waterschade') }\end{array}$ & $\begin{array}{l}\text { https://www.wur.nl/en/show/Wijs-met- } \\
\text { Waterschade.htm }\end{array}$ & \\
\hline WR & WLR & ASG & Luuk Gollenbeek & luuk.gollenbeek@wur.nl & $\begin{array}{l}\text { Manure with value, valuable } \\
\text { content from calf manure; } \\
\text { Netherlands next level manure } \\
\text { valuation; Biobased upgrading of } \\
\text { manure and digestate }\end{array}$ & $\begin{array}{l}\text { https://www.wur.nl/nl/project/Mest-vol-Waarden-II- } \\
\text {.htm }\end{array}$ & $\begin{array}{l}\text { https://www.wur.nl/nl/Onderzoek- } \\
\text { Resultaten/Onderzoeksprojecten- } \\
\text { LNV/Expertisegebieden/kennisonline/ } \\
\text { Next-Level-mestverwaarden.htm }\end{array}$ \\
\hline WR & WLR & ASG & Marion de Vries & marion.devries@wur.nl & $\begin{array}{l}\text { Route map to climate smart dairy } \\
\text { farms }\end{array}$ & $\begin{array}{l}\text { https://www.wur.nl/nl/project/Routekaart-voor- } \\
\text { klimaatslimme-melkveehouderij-1.htm }\end{array}$ & \\
\hline WR & WLR & ASG & Michel de Haan & Michel.dehaan@wur.nl & $\begin{array}{l}\text { Surface and ground water via } \\
\text { dairy farms; Company water index } \\
\text { ('BedrijfsWaterWijzer') presenting } \\
\text { water based upon seven theme's. }\end{array}$ & $\begin{array}{l}\text { https://www.wur.nl/nl/Onderzoek- } \\
\text { Resultaten/Onderzoeksprojecten- } \\
\text { LNV/Expertisegebieden/kennisonline/Doorontwikkeli } \\
\text { ng-BedrijfSWaterWijzer-en-verbeteren- } \\
\text { waterprestaties.htm }\end{array}$ & www.koeienenkansen.nl \\
\hline WR & WMR & ASG & Dolfi Debrot & dolfi.debrot@wur.nl & $\begin{array}{l}\text { Redesign of adaptive building with } \\
\text { nature - Seafood production } \\
\text { networks for food and nutrition } \\
\text { security in stressed regions }\end{array}$ & $\begin{array}{l}\text { https://www.wur.nl/nl/Onderzoek- } \\
\text { Resultaten/Onderzoeksprojecten- } \\
\text { LNV/Expertisegebieden/kennisonline/Aquatische- } \\
\text { systemen.htm }\end{array}$ & \\
\hline WR & WMR & ASG & Henrice Jansen & henrice.jansen@wur.nl & $\begin{array}{l}\text { Implementation of new } \\
\text { technologies for food production; } \\
\text { Sustainable aquaculture. }\end{array}$ & $\begin{array}{l}\text { https://www.wur.nl/en/Research- } \\
\text { Results/kennisonline/Innovative-Aquaponics-for- } \\
\text { Professional-Application.htm }\end{array}$ & \\
\hline WR & WMR & ASG & $\begin{array}{l}\text { Jaap van der } \\
\text { Meer }\end{array}$ & jaap.vandermeer@wur.nl & Marine food systems & & \\
\hline
\end{tabular}




\begin{tabular}{|c|c|c|c|c|c|c|c|}
\hline WR & WMR & ASG & Marnix Poelman & marnix.poelman@wur.nl & $\begin{array}{l}\text { KB-project: Marine lower trophic } \\
\text { food systems; Proteins from saline } \\
\text { residual currents } 1 \text {; Proteins from } \\
\text { saline residual currents } 2 \text {. }\end{array}$ & $\begin{array}{l}\text { https://www.wur.nl/en/Research- } \\
\text { Results/kennisonline/Marine-lower-trophic-food- } \\
\text { systems.htm }\end{array}$ & \\
\hline WR & WMR & ASG & Reinier Nauta & reinier.nauta@wur.nl & $\begin{array}{l}\text { ProSeaweed: development of } \\
\text { seaweed production in the } \\
\text { Netherlands and the potential of } \\
\text { seaweed. }\end{array}$ & & \\
\hline WR & WPR & PSG & $\begin{array}{l}\text { Caroline van der } \\
\text { Salm }\end{array}$ & caroline.vandersalm@wur.nl & $\begin{array}{l}\text { Water and Nutrient efficiency in } \\
\text { greenhouse horticulture }\end{array}$ & $\begin{array}{l}\text { https://www.wur.nl/nl/Onderzoek- } \\
\text { Resultaten/Onderzoeksinstituten/plant- } \\
\text { research/glastuinbouw/Onderzoeksthemas/waternutr } \\
\text { ienten.htm }\end{array}$ & \\
\hline WR & WPR & PSG & $\begin{array}{l}\text { Corne } \\
\text { Kempenaar }\end{array}$ & corne.kempenaar@wur.nl & $\begin{array}{l}\text { National test site ('proeftuin') for } \\
\text { precision agriculture }\end{array}$ & $\begin{array}{l}\text { https://www.wur.nl/en/Research- } \\
\text { Results/kennisonline/Precisielandbouw-4.0.htm }\end{array}$ & \\
\hline WR & WPR & PSG & Ellen Beerling & ellen.beerling@wur.nl & $\begin{array}{l}\text { Zero emission cultivation; EIP pilot } \\
\text { Greenhouse horticulture Water } \\
\text { proof; Technology for waste water } \\
\text { treatment in greenhouse } \\
\text { horticulture }\end{array}$ & $\begin{array}{l}\text { https://www.wur.nl/en/Research- } \\
\text { Results/kennisonline/EIP-pilot-Glastuinbouw- } \\
\text { Waterproof.htm }\end{array}$ & $\begin{array}{l}\text { https://www.wur.nl/en/Research- } \\
\text { Results/kennisonline/KV-1509-031- } \\
\text { Technologie-voor-behandeling-van- } \\
\text { lozingswater-in-de-glastuinbouw.htm }\end{array}$ \\
\hline WR & WPR & PSG & $\begin{array}{l}\text { Rommie van der } \\
\text { Weide }\end{array}$ & rommie.vanderweide@wur.nl & $\begin{array}{l}\text { Green process water; Biobased } \\
\text { upgrading with digestate; ACRRES } \\
\text { (www.accres.nl) }\end{array}$ & $\begin{array}{l}\text { https://www.acrres.nl/projecten_acrres/biobased- } \\
\text { opwaarderen-mest-en-digestaat/ }\end{array}$ & $\begin{array}{l}\text { https://www.wur.nl/en/Research- } \\
\text { Results/kennisonline/Groen- } \\
\text { proceswater-2.htm }\end{array}$ \\
\hline WR & WPR & PSG & Wouter Verkerke & wouter.verkerke@wur.nl & $\begin{array}{l}\text { Redesign of production systems } \\
\text { for circular horticulture \& Bulb } \\
\text { cultivation }\end{array}$ & $\begin{array}{l}\text { https://www.wur.nl/en/Research- } \\
\text { Results/kennisonline/Redesign-of-production- } \\
\text { systems-for-circular-horticulture-bulb-cultivation.htm }\end{array}$ & \\
\hline WU & DEP & ASG & Johan Verreth & johan.verreth@wur.nl & $\begin{array}{l}\text { Nutrient dynamics in aquaculture } \\
\text { and fish cultivation. Emeritus } \\
\text { chairholder Aquaculture \& } \\
\text { Fisheries }\end{array}$ & & \\
\hline WU & DEP & AFSG & Cees Buisman & cees.buisman@wur.nl & & & \\
\hline WU & DEP & AFSG & Huub Rijnaarts & huub.rijnaarts@wur.nl & $\begin{array}{l}\text { Research on reusage of water } \\
\text { including soils and sediments for } \\
\text { cleaner production processes and } \\
\text { sustainable resource chains }\end{array}$ & & \\
\hline
\end{tabular}




\begin{tabular}{|c|c|c|c|c|c|c|c|}
\hline WU & DEP & AFSG & Rene Wijffels & rene.wijffels@wur.nl & $\begin{array}{l}\text { Development and research on the } \\
\text { production of new production } \\
\text { systems for biobased products } \\
\text { including (micro) algae. }\end{array}$ & & \\
\hline WU & DEP & ASG & Geert Wiegertjes & geert.wiegertjes@wur.nl & $\begin{array}{l}\text { Sustainably cultivation of } \\
\text { (shell)fish }\end{array}$ & $\begin{array}{l}\text { https://www.wur.nl/en/Research-Results/Chair- } \\
\text { groups/Animal-Sciences/Aquaculture-and- } \\
\text { Fisheries.htm }\end{array}$ & \\
\hline WU & DEP & ESG & Bart Koelmans & bart.koelmans@wur.nl & & & \\
\hline WU & DEP & ESG & Carolien Kroeze & carolien.kroeze@wur.nl & $\begin{array}{l}\text { Research on the understanding of } \\
\text { the earth and climate systems } \\
\text { from a human dimension. }\end{array}$ & & \\
\hline WU & DEP & ESG & $\begin{array}{l}\text { Jordi Vila-Guerau } \\
\text { de Arellano }\end{array}$ & jordi.vila@wur.nl & $\begin{array}{l}\text { Research on the interaction } \\
\text { between (the lower levels of) the } \\
\text { atmosphere and } \\
\text { vegetation/surface area. }\end{array}$ & $\begin{array}{l}\text { https://www.wur.nl/nl/Personen/Jordi-prof.dr.-J- } \\
\text { Jordi-Vila-Guerau-de- } \\
\text { Arellano.htm?subpage=contactperson }\end{array}$ & \\
\hline WU & DEP & ESG & Petra Hellegers & petra.hellegers@wur.nl & $\begin{array}{l}\text { Research on the role of water in } \\
\text { agriculture in the broadest context } \\
\text { possible. }\end{array}$ & $\begin{array}{l}\text { https://www.wur.nl/en/Research- } \\
\text { Results/kennisonline/Adaptive-water-management- } \\
\text { in-relation-to-climate-change.htm }\end{array}$ & \\
\hline WU & DEP & ESG & Rachel Creamer & rachel.creamer@wur.nl & Soils in a changing climate & & \\
\hline WU & DEP & ESG & Ton Hoitink & ton.hoitink@wur.nl & $\begin{array}{l}\text { Research on hydrological } \\
\text { processes on a basin level by using } \\
\text { advanced measuring methods, } \\
\text { models and assimilation } \\
\text { techniques. }\end{array}$ & $\begin{array}{l}\text { https://www.wur.nl/nl/Onderzoek- } \\
\text { Resultaten/Onderzoeksinstituten/Environmental- } \\
\text { Research/Programmas/Duurzaam- } \\
\text { waterbeheer/Water-in-een-verstedelijkende- } \\
\text { omgeving.htm }\end{array}$ & \\
\hline WU & DEP & PSG & Ken Giller & ken.giller@wur.nl & $\begin{array}{l}\text { Research on sustainability and } \\
\text { resilience of farming systems; } \\
\text { WaCASA - Wageningen Centre for } \\
\text { Agroecology and System Analysis }\end{array}$ & $\begin{array}{l}\text { https://www.wur.nl/en/Research-Results/Chair- } \\
\text { groups/Plant-Sciences/Plant-Production-Systems- } \\
\text { Group.htm }\end{array}$ & \\
\hline WU & DEP & PSG & Rogier Schulte & rogier.schulte@wur.nl & $\begin{array}{l}\text { Research on sustainable } \\
\text { agriculture and redesigning it }\end{array}$ & & \\
\hline
\end{tabular}




\begin{tabular}{|c|c|c|c|c|c|c|c|}
\hline WU & DEP & SSG & Han Wiskerke & han.wiskerke@wur.nl & $\begin{array}{l}\text { SUPURBFOOD; Short chains, } \\
\text { urbanization, ecological } \\
\text { performance local food system, } \\
\text { closing circular systems. ROBUST; } \\
\text { urban-countryside relations in } \\
\text { which ecosystem services (e.g. } \\
\text { water storage and management) } \\
\text { are the main topic. }\end{array}$ & www.supurbfood.eu & www.rural-urban.eu \\
\hline WUR & $\mathrm{N} / \mathrm{A}$ & N/A & N/A & N/A & $\begin{array}{l}\text { Community of Practice; Salt } \\
\text { tolerance }\end{array}$ & $\begin{array}{l}\text { https://www.wur.nl/nl/Onderzoek- } \\
\text { Resultaten/Onderzoeksprojecten- } \\
\text { LNV/Expertisegebieden/kennisonline/Community-of- } \\
\text { Practice-zouttolerantie-1.htm }\end{array}$ & \\
\hline WUR & $\mathrm{N} / \mathrm{A}$ & N/A & N/A & N/A & $\begin{array}{l}\text { Knowledge theme on circular } \\
\text { economy, a central portal }\end{array}$ & $\begin{array}{l}\text { https://www.wur.nl/nl/Onderzoek- } \\
\text { Resultaten/Onderzoekprogrammas/Onderzoeks-en- } \\
\text { investeringsprogrammas/Circulair-verbonden.htm }\end{array}$ & \\
\hline
\end{tabular}

